\title{
Temporary Streams in a Peatland Catchment: Pattern, Timing, and Controls on Stream Network Expansion and Contraction.
}

\begin{tabular}{|r|l|}
\hline Journal: & Earth Surface Processes and Landforms \\
\hline Manuscript ID: & ESP-13-0037.R1 \\
\hline Wiley - Manuscript type: & Special Issue Paper \\
\hline Complete List of Authors: & $\begin{array}{l}\text { Goulsbra, Claire; The University of Manchester, Geography } \\
\text { Evans, Martin; University of Manchester, School of Environment and } \\
\text { Development } \\
\text { Lindsay, John; University of Guelph, Geography }\end{array}$ \\
\hline Keywords: & $\begin{array}{l}\text { Ephemeral Streamflow, Hydrological Connectivity, Peatland Hydrology, } \\
\text { Drainage Density, Runoff Generation }\end{array}$ \\
\hline & \\
\hline
\end{tabular}

SCHOLARONE ${ }^{\mathrm{m}}$

Manuscripts 
1 Temporary Streams in a Peatland Catchment: Pattern, Timing, and Controls on

2 Stream Network Expansion and Contraction.

3

4 C. Goulsbra (1), M. Evans (1), and J. Lindsay (2)

5

6 (1) Upland Environments Research Unit, School of Environment and Development,

7 University of Manchester, United Kingdom (claire.goulsbra@manchester.ac.uk), (2)

8 Department of Geography, University of Guelph, Guelph, Canada

10 ABSTRACT

11 In peatlands, poorly maintained baseflows mean that network expansion during

12 storm events can be rapid and pronounced, resulting in large changes in catchment

13 connectivity. This has implications for the timing and magnitude of material fluxes

14 from these environments, understanding of which is becoming increasingly important

15 due to peatlands' significance as global carbon stores. In this study, Electrical

16 Resistance (ER) technology has been used to create sensors capable of detecting

17 the presence and absence of flow in ephemeral portions of the channel network.

18 These sensors provide data on the patterns of network variation in the Upper North

19 Grain research catchment, a small peatland headwater catchment in the South

20 Pennines, UK. Networks of around 40 sensors were deployed in autumn 2007 and

21 summer 2008, giving a total of almost 4 months of high-resolution monitoring data.

22 Drainage density in the catchment was found to vary between 1.4 and $30.0 \mathrm{~km} / \mathrm{km}^{2}$,

23 suggesting significant differences in connectivity between the expanded and

24 contracted networks. Water table depth was identified as the key factor determining

25 the temporal pattern of stream flow at both the site- and catchment-wide scales. In 
26 terms of the spatial pattern of flow, network expansion and contraction occurred in a

27 disjointed pattern, occurring in a similar pattern between events, suggesting that

28 localised controls are important for flow generation. Spatial controls on flow

29 generation relate to local water table levels, and include drainage area, local

30 dissection, channel slope and gully morphology. The importance of water table as

31 the key control on catchment connectivity suggests that potential future change in

32 catchment water tables associated with projected climate change or with peatland

33 restoration by rewetting will modify the frequency of full catchment connectivity.

34

35 Short title: Temporary Streams in a Peatland Catchment.

36 Keywords: Ephemeral Streamflow, Hydrological Connectivity, Peatland Hydrology,

37 Drainage Density, Runoff Generation. 


\section{INTRODUCTION}

39 Concepts of hydrological and geomorphological connectivity have been widely discussed in the last decade (Bracken and Croke, 2007; Fryirs et al., 2007; Wainwright et al., 2011; Bracken et al., 2013). Advancing our understanding of system connectivity has an important role in the development of modelling approaches (Lexartza-Artza and Wainwright, 2009) and is key to effective environmental management.

Bracken et al. (2013) identify connectivity as an important framework for the analysis of runoff and runoff generation with overland flow and subsurface flow as key mechanisms generating catchment connectivity. They argue that a process based understanding of connectivity is a prerequisite for effective catchment management.

50 Within this definition they recognise two key types of connectivity which are structural

51 connectivity and process-based connectivity. Structural connectivity is a function of

52 the physical adjacency of landscape units and evolves only at the timescale of morphological change in the landscape system, whereas process-based connectivity relates to the dynamic evolution of connected flow pathways within a catchment or

55 land system at timescales driven by synoptic or seasonal changes in hydro 56 meteorology.

58 A major focus of current work on process based connectivity has been the development of hillslope channel linkages driven by the development of overland flow (Gomi et al., 2008; Reaney et al., 2013) or sub surface flow (McGuire and

61 McDonnel, 2010; Wainwright et al., 2011). However, an aspect of connectivity which 62 has received less recent attention is the temporal variability of the connected 
63 channel system. In strongly ephemeral systems this problem effectively spans the

64 definition of structural and process based connectivity since the adjacency of

65 hillslopes to active channel systems changes at synoptic timescales in response to

66 the development of connected flow in upper channel reaches.

67

68 Ephemeral streams

69 A number of studies of ephemeral stream system connectivity were undertaken in

70 the two decades post 1960 but recent interest in this area has been somewhat

71 limited. Intermittent and ephemeral streams have been observed in a variety of

72 environments as the extent of the flowing stream network expands from the

73 perennial channels into headwater reaches during stormflow events. These temporal

74 variations in the extent of the flowing stream network can lead to dramatic variations

75 in the drainage density within a catchment and many studies have reported drainage

76 densities of the fully expanded drainage network to be several times that of the

77 perennial 'contracted' network (i.e. Roberts and Klingeman, 1972; Day, 1980). The

78 ranges of drainage density values found in a selection of these studies are presented

79 in Table 1.

80

81 Three patterns of network expansion have been observed. The first is 'bottom-up'

82 expansion. As the catchment becomes wetter, the water table rises and there is a

83 progressive up-slope movement of the ground-surface intersection of the water

84 table, causing the head of the stream network to gradually extend up stream. As the

85 catchment dries out, the water table drops and the flowing channel head recedes

86 downstream (Morgan, 1972). The second is a disjointed pattern of network

87 expansion where surface flow occurs in discrete segments of the channel which 
expand and contract in an upstream and/or downstream direction. This is thought to be due to the effect of localised physical controls, such as saturated slopes and depressions around the flowing channel. Network contraction may also be disjointed, with flow disintegrating into several flowing segments (Day, 1978; 1980). The third pattern is 'top down' growth, whereby flow begins from an upper section of the catchment from saturated areas, which then flows downslope and becomes part of a larger flowing network (Day, 1978).

Previous studies have found that variations in network extent are related to both transient characteristics of the catchment (temporal variations), including precipitation (Gregory and Walling, 1968; Morgan, 1972) and antecedent moisture conditions (Gurnell, 1978), and to more permanent characteristics (spatial variations) including water table levels (Day, 1978), lithology (Gurnell, 1978; Day, 1980), soil properties such as compaction (Gurnell, 1978) and infiltration capacity (Wingington et al., 2005), vegetation type and amount (Gregory and Walling, 1968; Day, 1978; Gurnell, 1978), drainage area (Day, 1980; Fritz et al., 2008), catchment and channel slope (Day, 1980), subsurface piping (Morgan, 1972), and localised in-channel controls, including channel morphology (Day 1978; 1980).

Changes in drainage density and the associated changes in connectivity have important implications in terms of the timing and magnitude of catchment discharge and the source areas of sediments and solutes. For example, a greater density of flowing channels increases drainage efficiency as the distance that runoff must travel to a channel decreases. As channelised flow reduces travel times, this means that greater quantities of water travel to the basin outlet faster, thereby increasing peak 
113 flows (Kirkby, 1975). In fact, many studies on network expansion have found that

114 changes in drainage density are highly correlated with changes in discharge

115 (Gregory and Walling, 1968; Blyth and Rodda, 1973; Day, 1978). In addition, the locations of flow within the channel network have been found to vary during changes in network extent (Day, 1980), suggesting that it is possible to determine which portions of a basin contribute most to runoff (Blyth and Rodda, 1973).

Changes in network extent may also impact upon water quality. The greater connectivity associated with an expanded stream network can lead to an increase in non-point source pollutants directly entering stream channels (Wingington et al., 2005). The rewetting of ephemeral parts of the channel may also affect the fate of nutrients and organic matter that accumulate during the dry period, as the inundation of dry organic matter may release large quantities of dissolved organic carbon (DOC) (e.g. 'blackwater events', Bond and Cottingham, 2008). Therefore, both the quantity expansion in hydrological models could potentially lead to significant improvements in prediction accuracy.

\section{Dynamic Connectivity in Peatlands}

133 Significant variations in network extent have been observed in peatlands (Bay, 1969;

134 Holden and Burt, 2003), where baseflows are often so poorly maintained due to the

135 limited amount of seepage that many small streams dry up completely, particularly

136 during the dry season (Burt et al., 1990). This has implications for connectivity, as a

137 fully expanded drainage network represents a significantly higher degree of 
138 connectivity within a catchment than the contracted perennial network. In terms of 139 the hydrology of these systems, blanket peatlands are renowned for their 'flashy' 140 hydrological regimes as water is rapidly and efficiently transferred from the hillslopes

141 to the channel, resulting in short lag times and large storm peaks. Consequently 142 blanket peat catchments tend to be sources of flooding rather than attenuators of 143 flow (Holden and Burt, 2003). Where peatlands are eroded, as is the case for most 144 U.K. upland systems (Evans and Warburton, 2007), large quantities of sediment are also removed. This has several repercussions. Firstly, it can result in the infilling of reservoirs and water discolouration, leading to problems for water resource managers (Butcher et al., 1992; Worrall et al., 2002). Secondly, it has implications for carbon storage. Peat erosion by water leads to an increased fluvial flux of carbon out of peatland catchments, potentially turning them from carbon sinks to sources (Worrall et al., 2003; Pawson et al., 2012.). Upland peatlands in the Southern Pennines, U.K. are also severely polluted (Rothwell et al., 2007). Significant concentrations of heavy metals are transported in particulate and dissolved form in peatland streams with potential implications for aquatic ecosystems and drinking water supplies downstream (Rothwell et al., 2007). Although network expansion has been previously observed in peatland systems it has not been well studied. A proper understanding of the dynamic connectivity of peatland catchments is therefore required to understand the role of connectivity in controlling material fluxes from eroding peatland systems.
A key influence on this dynamic connectivity is the temporal and spatial pattern of runoff production. In ombrotrophic peatland systems the dominant runoff producing mechanism is saturation-excess overland flow, so that temporal patterns of runoff 
163 are strongly controlled by antecedent moisture conditions, with significant volumes of

164

165

166

167

168

169

170

171

172

173

174

175

176

177

178

179

180

181

182

183

184

185

186 runoff only generated when water tables are at or close to the surface (Evans et al., 1999; Holden and Burt, 2003; Daniels et al., 2008). Similarly, spatial variations in runoff are driven by the spatial pattern of water table level, influenced by both topography (Holden and Burt, 2003; Allott et al., 2009) and drainage. This 'drainage' may take two main forms; drainage ditches deliberately cut into the peat (Holden et al., 2006) or erosional gullies which act as 'natural' drainage channels (Daniels et al., 2008). Pipe networks and macropore flow have also been found to make significant contributions to catchment discharge, with piping being a common feature in peatland catchments (Holden, 2006). For example, Holden and Burt (2003) found that up to $10 \%$ of runoff may travel through the pipe network at Moor House in the North Pennines. Therefore, the location and density of pipe outlets may also influence which portions of the stream network are active at any given time.

\section{Aims and Objectives}

The logistical demands of mapping channel extent mean that there is little empirical evidence on the spatial patterns of dynamic ephemeral channels. It is likely that these logistical difficulties have limited the scope of previous work. However, upsurge of interest in catchment connectivity in the last decade has coincided with the increasing availability of low cost approaches to extensive monitoring of streamflow (Goulsbra et al., 2009; Bhamjee and Lindsay, 2011, Bracken et al., 2013). This paper aims to take advantage of these approaches to develop understanding of connectivity in peatland stream systems. Upland peatland systems have a high proportion of temporary streams, and are systems where understanding 
187 of water and sediment flux has important implications for pollutant flux and carbon 188 budgets. Thus, this paper has four main objectives:

\section{METHODS}

\section{Study Site}

The study took place in the Upper North Grain catchment, a small headwater catchment of the River Ashop, which feeds the Ladybower Reservoir in the Upper Derwent Valley, South Pennines, UK (Figure 1). The field site was selected as a typical example of a severely gully eroded blanket peatland of the type widespread across upland Britain. The catchment has been closely monitored over a number of years, so that there is good contextual data for this study (e.g. Daniels et al., 2008; Rothwell et al., 2005, 2007). The catchment is $0.434 \mathrm{~km}^{2}$ in size to the pressure transducer which monitors stage, and $0.490 \mathrm{~km}^{2}$ to the confluence with a major adjacent tributary (Figure 1), lying between altitudes of around 480 and $540 \mathrm{~m}$. The principle land cover is blanket peat with maximum depths of $4 \mathrm{~m}$. The catchment has a vegetative cover comprising predominantly Eriophorum vaginatum, Calluna vulgaris, Erica tetralix, Vaccinium myrtillus, Empetrum nigrum and patches of Sphagnum spp. Mean monthly temperature for the Upper North Grain catchment from the period 2007 to 2009 is $7.0^{\circ} \mathrm{C}$ and mean annual precipitation is $1513 \mathrm{~mm}$. 
213 The catchment is heavily eroded with deep Bower Type I peat gullies (Bower, 1961)

214 often cut to the base of the peat, although some gullies have begun to revegetate

215 (Crowe et al., 2008). The topography of the catchment therefore effectively dictates

216 the channel system as these gullies concentrate flow, and channels are found within

217 the gully floors. The flashy hydrological regime and poor drainage of the peat mean

218 that ephemeral streams are found in this channel system. Most of the gullies in the

219 catchment directly connect to perennial channel system (Figure 1). However, in a

220 small number of gullies, flow is less topographically constrained at the interface

221 between the hillslope and the perennial channel. In these cases, water travels short

222 distances in the form of concentrated overland flow before reaching the main

223 channel. Outside of the gully network, flow remains unchannelised as diffuse

224 overland flow or subsurface storm flow. Piping is also prevalent in the catchment,

225 with a high density of outlets, particularly in more mature gullies (Wallet, 2004).

226

227 Instrumentation

228 The catchment is instrumented with a Skye automatic weather station (AWS) which

229 monitors precipitation and water table depth (Figure 1). Precipitation was recorded at

230 hourly intervals using a Campbell Scientific tipping bucket rain gauge, with tipping

231 intervals of $0.202 \mathrm{~mm}$. Water table elevation was recorded at hourly intervals using

232 an Intelisys pressure transducer at a single dipwell. The dipwell was constructed

233 from polypropylene waste pipe with an internal diameter of $30 \mathrm{~mm}$, with $5 \mathrm{~mm}$

234 diameter perforation holes at $100 \mathrm{~mm}$ intervals. All water table values referred to

235 from here on in refer to water table measured at the AWS. This is a wet blanket peat

236 site with high mean water table. The water table values reported are not intended to 
237 be representative of the entire catchment, but rather provide a relative measure of

238 relative antecedent moisture conditions. Shorter term measurements at other

239 catchment sites indicate that the AWS site is representative of broad temporal trends

240 in catchment water tables. Stage is monitored on the main stream channel of the

241 catchment, at a site which has a flat mineral base and is roughly box shaped (Figure

242 1). Stage was measured at 20 minute intervals using a Druck pressure transducer

243 and logged using a Skye Datahog. Stage was converted to discharge using a well-

244 established rating curve (Daniels, 2006).

245

246 Data on the presence or absence of flow were collected using the ephemeral

247 streamflow (ES) sensors developed by Goulsbra et al. (2009). These sensors are

248 based on electrical resistance sensors, which register high conductivity during flow

249 conditions when there is a continuous circuit between the sensor electrodes, and low

250 conductivity when flow is absent and the circuit is broken, providing binary data on

251 whether or not a reach is occupied by a temporary stream at any point in time. The

252 sensors used are Onset HOBO pendant $4 \mathrm{~K}$ temperature data loggers (product ID

253 UA-001-64) which have user-selectable sampling intervals of between $1 \mathrm{~s}$ and $18 \mathrm{~h}$,

254 and a $64 \mathrm{~K}$ memory storing over 52,000 readings. The loggers were converted to ER

255 sensors by the removal of the thermistor and the addition of two lengths of $0.3 \mathrm{~mm}$,

256 single strand, plastic insulated wire to form the sensor electrodes. Laboratory testing

257 carried out by Goulsbra et al. (2009) confirmed that the sensors are able to clearly

258 distinguish between the presence of water between the electrodes, irrespective of its

259 conductivity (a 'flow' or 'wet' reading), and the absence of water between the

260 electrodes (a 'dry' or 'no flow' reading). The electrodes were housed in a custom built

261 'sensor head', $42 \mathrm{~mm}$ in diameter and $50 \mathrm{~mm}$ in height (Goulsbra et al., 2009). This 
262 sensor head has several unique design features including a sunken sediment trap

263 which prevents false positive readings caused by deposition around the electrodes,

264 situating the electrodes in an optimal position for monitoring flow. The data collected

265 by the ES sensors requires only minimal processing; a threshold is set with all ER

266 readings below the threshold being defined as 'dry' or not flowing and those higher

267 being defined as 'wet' or flowing. Due to the significant difference between measured

268 ER during wet and dry conditions, this threshold can be set with confidence.

269

270 Field measurements

271 Data collection took place over two periods, autumn 2007 and summer 2008, in an

272 attempt to capture relatively dry conditions when the drainage network is likely to be

273 at its most dynamic. In autumn 2007 (11 September to 14 November), a network of

27441 ES sensors was installed over five gullies, shown by the pale grey circles in

275 Figure 1. One of the instrumented gullies discharges downstream of the pressure

276 transducer used to calculate discharge. This gully was instrumented in order to

277 capture a range of spatial characteristics of the gullies monitored and does not

278 compromise the results presented here. In summer 2008 (25 July to 8 September),

27940 ES sensors were installed over four gullies (black circles). To provide a

280 comparison between the two study periods, one of the gullies monitored in 2007 was

281 re-instrumented in 2008 (dark grey circles). ES sensors were sited where there was

282 a clearly incised single channel, as opposed to reaches where flow was diffuse or

283 channels braided, and on riffles rather than pools to avoid the sensors detecting

284 ponded water. Within a gully, ES sensors were located at approximately equal

285 intervals from the headwaters to the bottom of the gully (i.e. where the gully joins the

286 main channel), with a mean distance between ES sensors of $60 \mathrm{~m}$. 
288 Repeat field observations have shown the limit of the perennial flowing network to be 289 relatively stable, representing a drainage density of the contracted network of 1.41

$290 \mathrm{~km} / \mathrm{km}^{2}$, shown in Figure 1. The maximum total stream length is equivalent to the 291 total length of gullies in the catchment, at $14.70 \mathrm{~km}$, representing a drainage density 292 of the fully expanded network of $29.98 \mathrm{~km} / \mathrm{km}^{2}$. The combined coverage for the 2007 293 and 2008 monitoring constitutes $62 \%$ of this total stream length, at $9.08 \mathrm{~km}$, with the 294 contributing area for these streams equating to $55 \%$ of the catchment area, 295 representing a maximum drainage density of $33.52 \mathrm{~km} / \mathrm{km}^{2}$.

296

The loggers were set at sampling intervals of 1 minute, and downloaded approximately once every two weeks using a Hobo Waterproof Shuttle. During the 2007 study period problems were found with three of the ES sensors due to logger malfunction (1 site), damage to the equipment (1 site), or repositioning due to unsuitable bed morphology (1 site). This leaves a total of 38 sites which have continuous monitoring data. During the 2008 study period problems were found with three of the ES sensors due to damage to the equipment (1 site), or repositioning due to unsuitable bed morphology (2 sites), leaving 37 sites which have continuous monitoring data for the entire study period.

\section{Sources of spatial data}

High resolution LiDAR data are available for the catchment (2 m ground resolution, $250 \mathrm{~mm}$ z resolution), flown in 2002. A digital elevation model (DEM) of the catchment is shown in Figures 2 and 3. Terrain Analysis System (TAS) software (Lindsay, 2005) was used to extract various terrain attributes from the DEM, 
312 including slope, the wetness index (WI) (Beven and Kirkby, 1979), and the network

313 wetness index (NWI) (Lane et al., 2004). Two other sources of spatial data were

314 available for the catchment. The first of these was a gully map developed by Evans

315 and Lindsay (2010), shown in Figure 1. The areal extent of erosional gullies was

316 derived by combining areas of low difference from mean elevation and high positive

317 plan curvature, and gully depth is modelled by interpolating between gully edges.

318 The second is the water table model, developed by Allott et al. (2009) which predicts

319 the median water table depth at the site scale. The model does not predict the water

320 table in the gullies. Several characteristics of each site were recorded in the field,

321 including the width of the top of the gully, the width of the gully floor, and the depth of

322 the gully. Table 2 provides a summary of the spatial data collected for each site.

323 Note that some attributes relate to the catchment area of each site whilst others

324 relate to its specific location. As gullies tend to have very high associated slope

325 values due to their steep walls, this may have the effect of skewing catchment

326 averages for some attributes such as WI and NWI, as they are partially based on

327 slope. Therefore, average slope, WI and NWI were also calculated for each site's

328 contributing area excluding the area occupied by gullies (i.e. hillslopes only).

330 RESULTS

332 The Pattern of Stream Network Expansion

333 The processed data show the catchment response to a number of rainfall events

334 based on when each site goes from 'dry' to 'wet'. In each of the 2007 and 2008

335 datasets there was only one event which caused all the sites to go from 'dry' to 'wet'.

336 The timings and pattern of streamflow initiation for these two events are illustrated in 
337 Figures 2 and 3 respectively. Both figures show that the wetting up of the ephemeral

338

339

340

341

342

343

344

345

346

347

348

349

350

351

352

353

354

355

356

357

358

359

360 channels in this system is variable both within and between gullies. It seems that the pattern of network expansion is neither 'bottom up' nor 'top down', but in fact most

closely corresponds to the 'disjointed' pattern of network expansion described by

Day $(1978,1980)$. This suggests that local controls on runoff may be significant in terms of the generation of flow in ephemeral portions of the channel.

To determine if the pattern of drainage network expansion is consistent for different storms, Spearman's rank correlation analysis was used to compare the order in which sites became wet for different network expansion events. Only pairs of events where ten or more sites responded to both events were considered. Correlation matrices showing the results of Spearman's rank analysis for events in the 2007 and 2008 periods are displayed in Tables 3 and 4 respectively.

For the 2007 dataset, there were 9 pairs of events where ten or more sites responded to both events. Of these, three pairs of events showed no significant correlations between the order in which sites registered flow, one showed correlations significant at the 0.10 level, three at the 0.05 level, and two at 0.01 level (Table 3). On all three occasions where no significant relationship was found, one of the events was a storm on 5 November 2007. Before this event, the water table at the AWS was just $9 \mathrm{~mm}$ below the surface, compared to at least $34 \mathrm{~mm}$ for all other events. During this event, all sites that were previously dry became wet within one hour of the start of rainfall. There was just a 43 minute difference between the response of the first and last site. The high water tables and almost instantaneous 
361 wetting up of the catchment may explain why the pattern of network expansion during this event was different from the others.

363

\section{The Rate of Stream Network Expansion}

Substantial differences in the rate of network expansion can be observed in Figures 2 and 3. In the 2007 example (Figure 2) the first site responds five hours after rainfall initiation, with the last site responding a further 12 hours after this. This is in contrast to the 2008 example (Figure 3) where $63 \%$ of the sites respond within one hour of the start of rainfall, with all sites being wet three hours after this. In both examples water tables were low prior to the onset of rainfall (a drawdown of $212 \mathrm{~mm}$ in 2007 and $190 \mathrm{~mm}$ in 2008). The difference in the timing of network response is probably due to differences in the characteristics of the rainfall events, specifically rainfall intensity. In the 2008 example, rainfall intensities were much higher at the start of the 
386 rainfall event $(6.9 \mathrm{~mm}$ in the first hour) compared with the 2007 example $(5.2 \mathrm{~mm}$ in

38714 hours), giving rise to a more rapid expansion of the network.

388

389

390

391

392 conditions can affect the rate of network expansion.

This rapid streamflow response to high rainfall intensities can be seen at other points in both datasets. Table 5 shows the three events in each dataset where, with the exception of the examples shown in Figures 2 and 3, the highest number of sites went from dry to wet. In every example all sites went from dry to wet within a maximum of five hours of the initiation of rainfall. Variations in network response are evident within this dataset. For example, on 5 November 2007, all sites went from wet to dry within one hour of the start of rainfall. This is despite the fact that in the first hour of the storm, only $0.4 \mathrm{~mm}$ of rainfall fell. In contrast, by the second hour of the storms on 9 October and 28 October 2007 , totals of $0.8 \mathrm{~mm}$ and $1.0 \mathrm{~mm}$ of rainfall had fallen respectively, yet some sites remained dry. This was due to antecedent water table levels. On 5 November, the water table was just $9 \mathrm{~mm}$ below the surface, whereas it was at a depth of $34 \mathrm{~mm}$ on 9 October and $116 \mathrm{~mm}$ on 28 October. This would suggest that both rainfall characteristics and antecedent

\section{The Temporal Controls on Temporary Stream Flow}

Using the data from the ES sensors, there are three ways in which to describe the extent of the drainage network at any given time. The first is simply how many sites are 'wet' or 'dry', although this does not take into account the spatial arrangement of the locations of channel flow. The second is the number of sites which are both 'wet' and connected to the perennial stream network. The third is the drainage density of the monitored gullies based on the sites which are both wet and connected, with the 
411 gully network representing the maximum possible extent of the drainage network.

412 These three metrics were calculated at hourly intervals for both the 2007 and 2008

413 datasets (the sites which had gaps in monitoring data were not included).

414

415 A series of potential temporal controls on network extent were calculated using the

416 AWS data, including water table depth, total precipitation in the previous 1 - 12

417 hours, 1 - 6 days, and 1 - 4 weeks, and the number of hours since the last rainfall.

418 The only significant predictor for all three measures of network extent in both the

4192007 and 2008 datasets was the depth of the water table. For the 2007 dataset, $\mathrm{R}^{2}$

420 values for water table and the number of sites wet, the number of sites connected,

421 and the drainage density were $0.93,0.79$ and 0.84 respectively, and these values

422 were $0.91,0.75$ and 0.81 for the 2008 dataset. These relationships are shown in

423 Figures 4 and 5 . This suggests that the depth of the water table has a very strong

424 influence on network extent at the catchment scale.

425

426 At the site scale, the controls on the presence of flow were investigated using binary

427 logistic regression. This analysis used the wetness predictor variables described

428 above to determine the probability of flow at each site at hourly intervals. Where the

429 probability of flow is $<0.5$ the site is predicted to be dry; where the probability of flow

430 is $>0.5$ the site is predicted to be wet. Again, water table depth was the most

431 significant predictor variable for all sites, with significance levels consistently $<0.01$.

432 This allowed the calculation of a 'critical water table depth' at each site, below which

433 the site would be dry and above which the site would be wet. The regression

434 analysis has high accuracies of $94.8 \%$ and $95.8 \%$ for the 2007 and 2008 datasets

435 respectively. An example of this can be seen in Figure 6, showing the observed and 
436 predicted data for a site in the 2007 dataset. The critical WT depth set by the

437 regression analysis at this site is $22.6 \mathrm{~mm}$, with an accuracy of $97.4 \%$. It should be

438 noted here that it is unlikely that the water table as measured at the AWS is the

439 direct control upon flow at any site; rather local water tables may vary linearly with

440 the water table as measured at the AWS (an estimate of relative catchment

441 wetness).

442

443 Based on the data presented in Figure 6, it would seem that the critical water table 444 depth is a good predictor of the occurrence of channel flow. However, although this

445 may be true for sites which experience dry periods throughout the study period, this 446 may be less sound for sites which experience less transient flow. Figure 7 shows an 447 example of a site from the 2008 dataset. Binary logistic regression indicated a critical 448 water table depth of $123 \mathrm{~mm}$ at this site, with an accuracy of $99.9 \%$. However, 449 setting the threshold anywhere between 90 and $135 \mathrm{~mm}$ would give the same 450 accuracy as there is only one data point in this range throughout the study period 451 (representing $0.2 \%$ of the study period). This may make it difficult to pinpoint critical 452 water table depth for some sites which experience flow in all but the driest 453 conditions.

455 The Spatial Controls on Ephemeral Stream Flow

456 The propensity for a site to contain flow may be quantified by two key measures. The 457 first is the proportion of the study period during which each site is 'wet', and the 458 second is the critical water table depth at each site above which the site is predicted 459 to be wet, and below which dry, modelled using binary logistic regression as outlined 460 above. However, the proportion of time each site is wet is strongly linked to water 
461 table depths during the study period. As the distribution of water table depths during 462 the 2007 and 2008 monitoring periods differ, it is not appropriate to compare the 463 proportion of flow at each site from the different periods. However, the critical water 464 table depth at each site is insensitive to when the data were collected. The critical 465 water table depth has been calculated for sites in both monitoring periods for which 466 there is a complete, continuous dataset. Some sites in the gully that was 467 instrumented in both 2007 and 2008 displayed a disparity in the critical water table 468 threshold between the two years of data as the ES sensors could not be sited in exactly the same place. Where this was the case, data from the more recent 2008 dataset were used. The spatial pattern of the critical water table threshold at each site is displayed in Figure 8, with the small circles representing sites which are 472 'driest' and large circles those which are 'wettest' $(n=65)$.

474 Multiple linear regression was performed to see if the critical water table depth could 475 be successfully explained using the spatial characteristics of each site outlined in 476 Table 2. The very wet sites for which the critical water table depth could not be 477 pinpointed were excluded from the analysis. The model which performs the best is 478 shown in equation 1, where Contributing Area is the size of the catchment area of 479 each site $\left(\mathrm{m}^{2}\right)$, accounting for $18.5 \%$ of the variance in Critical Water Table Depth; 480 Average Gully Depth is the average gully depth (a measure of dissection) in the 481 contributing area of each site $(\mathrm{m})$, accounting for $8.9 \%$ of the variance; Depth Field 482 is the gully depth at each site as measured in the field $(\mathrm{m})$, accounting for $11.3 \%$ of 483 the variance; and Slope9 is the channel slope within a 9 grid cell reach of the site $484(\%)$, accounting for $12.9 \%$ of the variance in Critical Water Table Depth. All four 485 explanatory variables have a significance of $<0.001$. The model has an $R^{2}$ of 0.52 
486 (Adjusted $R^{2}=0.48$ ) and the standard error of the estimate is 27.4. The ANOVA F 487 statistic is 13.9 .

488

489

Critical WT depth $=49.042+(0.002$ * Contributing Area $)-(263.717$ * Average Gully

490

Depth $)+(29.686$ * Depth Field $)-(498.646$ * Slope9)

491

492

\section{Modelling Drainage Density Variations}

493

Due to the strong relationship between water table depth and flow incidence at each site, it was possible to model how network extent changes with water table level.

Using the critical water table threshold values for all sites, the number of sites 'wet', the number of sites connected, and the drainage density for each sub-catchment were calculated over a range of water table depths. The data from each subcatchment was then combined to calculate network extent for the entire monitored area over a range of water table values (Figure 9, top).

500

501 The long water table record for the catchment means that it is possible to calculate the frequency at which various water table depths are exceeded. Three years of water table data (1 July 2007 to 30 June 2010) were examined to determine the cumulative temporal distribution of water table depth, shown in Figure 10 alongside water table levels during the 2 monitoring periods in this study. Water table levels during the two monitoring periods are not atypical, particularly the autumn 2007 data which shows a similar distribution to the long term record. The long term water table data allowed the frequency of various network extents to be calculated (Figure 9, bottom). It was found that when water tables fall below $180 \mathrm{~mm}$, flow in ephemeral 510 channels is completely absent, being restricted to the perennial channel network. 
511 This represents a drainage density of $1.41 \mathrm{~km} / \mathrm{km}^{2}$ and occurs around $13 \%$ of the

512 time. Complete connectivity of the fully expanded network is not achieved until water

513 tables are within $3 \mathrm{~mm}$ of the surface (at the AWS site), which occurs $39 \%$ of the

514 time. This represents a drainage density of $29.98 \mathrm{~km} / \mathrm{km}^{2}, 20$ times greater than that

515 of the contacted perennial network. For the remaining $48 \%$ of the time the extent of

516 the network varies between these two extremes.

517

518 Drainage Density and Discharge

519 The relationship between discharge and drainage density at hourly intervals during

520 both the 2007 and 2008 study periods is plotted in Figure 11. It is apparent that a

521 range of drainage density values were observed when the discharge was low, and a

522 range of discharge values were observed when the drainage density was high.

524 An example of this can been seen in Figure 12, which shows how the three key

525 descriptors of network extent, water table and discharge varied over the course of a

526 storm on $19-20$ September 2007. At the start of the storm (12:00 on 19

527 September), small inputs of relatively low intensity rainfall lead to recharge of the

528 water table and flow was produced at several of the sites. However, there was

529 almost no increase in discharge at the catchment outlet, and not until the rainfall

530 intensity increased to $15.75 \mathrm{~mm} \mathrm{~h}^{-1}$ at 03:00 on 20 September did discharge

531 increase. Peak discharge occurred at 04:00 (when the water table was $1 \mathrm{~mm}$ below

532 the surface). This was coincident with the peak in the proportion of sites wet, sites

533 connected and drainage density, which all reached their maximum at 04:00. Upon

534 the cessation of rainfall, discharge decreased rapidly, returning to baseflow levels by

535 around 14:00. Although water table levels and all three measures of network extent 
536 also decreased upon the cessation of rainfall, this was much less rapid, and levels

537 remained much higher than before the rainfall event.

538

539 DISCUSSION

540 This study has demonstrated that ES sensors can be used to detect streamflow in

541 ephemeral portions of the channel network, enabling the collection of high temporal

542 and spatial resolution data on ephemeral streamflow in the Upper North Grain

543 catchment. The data collected on variations in network extent represent perhaps the

544 most comprehensive dataset on network expansion and contraction currently

545 available.

546

547 Water Table as a Key Control

548 Much of the data on the timing of the production of flow in ephemeral portions of the

549 channels ties in with established notions of peatland hydrology and are consistent

550 with the dominance of saturation excess overland flow as the primary mechanism for

551 runoff generation (Evans et al., 1999; Holden and Burt, 2003). The rate of network

552 expansion has been found to be dependent on both antecedent conditions and

553 rainfall characteristics, being rapid when water tables are high and rainfall is intense.

554 When water tables are low, incident rainfall infiltrates into the peat until water tables

555 are at or close to the surface; only then does widespread runoff occur. This leads to

556 a longer delay in runoff production when water tables or rainfall intensities are low.

557

558 This dependence on water table levels is further evidenced by the strong relationship 559 between catchment-wide network expansion and water table level. It is also apparent 
560 at the site scale, with the incidence of flow at any site being strongly dependent on

561 water table level.

562

563 Spatial Patterns of Ephemeral Flow

564 In terms of the pattern of network expansion and contraction, the wetting up of the

565 ephemeral channels is variable both within and between gullies. Network expansion

566 is neither 'bottom up' nor 'top down', but most closely corresponds to the 'disjointed'

567 pattern of network expansion described by Day $(1978,1980)$. The pattern of network

568 expansion is similar between storms, with sites wetting up in a similar order each

569 time, particularly when storms are similar in terms of antecedent water table levels

570 and rainfall characteristics. This suggests that local controls on runoff may be

571 significant in terms of the generation of flow in ephemeral portions of the channel.

573 When examining the spatial controls on site wetness, the most significant model

574 accounted for $52 \%$ of the observed variance. The size of each site's contributing

575 area is significant, with sites with a larger contributing area containing flow more of

576 the time. This is likely to be because larger catchment areas take longer to drain,

577 thus flows are more prolonged. The degree of dissection of this contributing area is

578 also important, as represented the average gully depth variable in Equation [1]. Sites

579 with a more heavily dissected contributing area, indicated by a high average gully

580 depth, tend to be drier. This is likely to be due to the water table drawdown

581 associated with gullying (Daniels et al., 2008; Allott, 2009), reducing surface

582 saturation, and therefore, runoff production. In addition to the characteristics of a

583 site's contributing area, site specific characteristics have also been found to be

584 important. Sites with high channel slope tend to be drier as these sites are well 
585 drained and water is rapidly evacuated downstream. Many of these factors can be 586 seen to influence local water table, with sites which have a smaller, more dissected contributing area and high local channel slopes having deeper local water tables.

588

The final explanatory factor relates to gully morphology, with deeper gullies tending to be wetter. This may be due to the influence of pipeflow. It has been found that soil pipe density significantly and linearly increases with age of drainage in blanket peat 592 (Holden, 2006). If gully depth can be taken as a proxy for age then this may indicate that deep gullies may have a higher density of soil pipes. This was found by Wallet experience prolonged flow.

Although the majority of the variation in site wetness can be explained by the spatial factors examined here, $48 \%$ of the variation in flow occurrence cannot be explained by the factors outlined in Table 2, suggesting that the controls on flow production may be factors which have not been considered. The first possible influence is pipeflow. Although pipeflow may be correlated with gully depth to some degree, local of pipe outlets and the nature of pipeflows in the catchment may help to explain 
610 some of the variance in channel flow which is unaccounted for. A second possible

611 factor is small scale variations in channel bed topography that are unable to be

612 detected at the scale of the DEM.

613

614 Models of Dynamic Connectivity

615 As the monitored sites all show a strong dependence on water table level, it was

616 possible to model how network extent, and by implication, connectivity, varied with

617 water table in the instrumented gullies. The increase in drainage density of over

$6182,000 \%$ observed in this study is large when compared to the findings of other

619 studies (Table 1). The high maximum drainage densities reported in the Upper North

620 Grain study catchment are characteristic of eroded peatlands, and the large range in

621 observed drainage density is effectively a function of the high degree of ephemerality

622 of the headwater streams.

623

624 Drainage Density and Discharge

625 It appears that the relationship between discharge and drainage density observed by

626 other studies (i.e. Gregory and Walling, 1968; Blyth and Rodda, 1973; Day, 1978)

627 does not hold in this catchment. Rather, the data presented in Figures 11 and 12

628 suggest that there are two quite distinct states, when the catchment may be thought

629 to be relatively hydrologically active, and hydrologically inactive.

630

631 Following wet antecedent conditions, incident rainfall causes discharge to increase

632 rapidly from baseflow to stormflow. The high water tables at these times also give

633 rise to a fully expanded drainage network. This represents a hydrologically active

634 catchment, depicted by the vertical 'edge' of the data in Figure 11, and the peak in 
635 discharge at 04:00 on 20 September 2007 in Figure 12. When rainfall ceases, 636 discharge rapidly returns to baseflow values as storm runoff is evacuated from the 637 catchment. Drainage density values during baseflow conditions vary as the water 638 table drops. This represents a hydrologically inactive catchment, depicted by the 639 horizontal 'edge' of the data in Figure 11, and from 06:00 on 20 September 2007 in 640 Figure 12.

642 The catchment may also be thought of as hydrologically inactive during rainfall 643 events which occur following dry antecedent conditions, as shown by the period up 644 to $06: 00$ on 20 September 2007 in Figure 12. The absence of any increase in 645 discharge during this period, despite rainfall additions, is likely to be due to a lowered 646 water table, so that most of the incident rainfall infiltrates into the peat to make up 647 this deficit. The incidence of channel flow as detected by the sensors may have been 648 due solely to rain falling directly into the channel or localised areas of runoff.

649 However, this water did not reach the channel outlet, possibly because the water in 650 the channel was only enough to generate localised areas of ponding as opposed to 651 connected flow, or because it re-infiltrated into the channel bed at some downstream 652 point. Again, these variations in network extent despite discharge remaining at 653 baseflow levels is depicted by the horizontal 'edge' of the data in Figure 11, and 654 represents a hydrologically inactive catchment.

656 The evidence above suggests that drainage density does not influence discharge; 657 rather water table levels influence both the production of runoff and drainage density. 658 The data also indicate relatively rapid switching between a connected state and a 
659 disconnected state. This again highlights the importance of water table on peatland 660 hydrology and the 'flashy' nature of runoff production in peatlands.

661

662 Implications for Material Flux and Catchment Management.

663 Previous work on peatland sediment systems has demonstrated the importance of 664 sediment supply as a control on sediment flux, particularly emphasising the 665 importance of temporal variation in supply (Evans and Warburton, 2007). The 666 significant changes in drainage density observed in this study and the consequent 667 expansion of the connected sediment supply and reduction in hillslope sediment 668 transport path lengths suggest that spatial controls on sediment supply are equally 669 important in controlling storm sediment flux.

671 The dominance of water table (catchment wetness) in controlling catchment 672 connectivity, and potentially therefore material flux, has implications for the 673 management of peatland catchments into the future. Changes to the water table 674 regime induced by future climate conditions will have implications for the periodicity 675 and magnitude of fluxes. Projected wetter winters and drier summers across upland 676 peatlands (Clark et al. 2010) imply stronger seasonal variability in water table and 677 consequently in catchment connectivity. A second potentially significant driver of 678 water table change across many UK upland systems is peatland restoration through 679 the blocking of drainage ditches and erosional gullies (Ramchunder et al., 2009).

680 Elevated water tables associated with peatland restoration are likely to drive 681 increased channel connectivity and drainage density and may impact on the 682 periodicity of material flux from peatlands. 


\section{Further Work}

685 These potential changes in connectivity linked to climate change and peatland

686 restoration are an important area for further work. A related question in the context of

687 assessing the impact of connectivity changes on sediment flux is investigation of the

688 linkage between the lower reaches of ephemeral gullies and the perennial stream

689 system. In this study the four dendritic gullies instrumented to the north and east of

690 the catchment grade evenly to the head of the perennial stream channel. The four

691 gullies to the south and west which are approximately normal to the main stem drain

692 at their outlets a short distance across vegetated valley sides and floodplains. These

693 steep links are equivalent to the vegetated interface between slopes and channels

694 identified in re-vegetated gully systems in the North Pennines by Evans and

695 Warburton (2005). These slopes have been identified as zones of disconnection in

696 the sediment system. Because the flow in these zones was not channelised it did not

697 form part of the monitoring campaign in this study, but there is potential, at least in

698 the context of sediment flux, that the effective connectivity in the system is somewhat

699 less than indicated by measurement of drainage density. This is an area which

700 requires further work.

702 Further work on the impact of connectivity changes on the quantitative hydrology of

703 the catchment could consider the extent of the network not only in terms of its linear

704 dimensions (i.e. total stream length/drainage density), but in terms of its total volume

705 (Gregory and Ovenden 1979). A consideration of network volume may produce a

706 stronger relationship with discharge and would also give a clearer indication of the

707 spatial controls on runoff within the catchment. 


\section{CONCLUSIONS}

710 The use of a high density network of low cost wetness sensors has, for the first time,

711 empirically described spatial and temporal patterns of channel wetting in peatland

712 systems. The key findings are:

713 1. Catchment water table is the dominant control on channel wetness and the

714 channel network exhibits a rapid transition from a disconnected state to a

715 connected state as the catchment soils approach saturation.

716 2. Channel wetting occurs in a disjointed manner, controlled by both upstream

717 catchment conditions (specifically the size and degree of dissection of each site's

$718 \quad$ contributing area) and local channel slope.

7193 . This typical gullied headwater peatland system experiences in excess of an order 720 of magnitude change in drainage density between dry and fully saturated

721 conditions. The strongly episodic nature of sediment and solute fluxes from

722 peatland systems (Evans and Warburton, 2007) is consistent with catchment

723 connectivity being a key control on material flux from peatland systems.

724 4. Future change in peatland water tables driven by climate change or peatland

725 restoration are likely to modify the degree of connectivity in ephemeral headwater 726 streams.

728 ACKNOWLEDGEMENTS

729 LiDAR data was flown for the National Trust and used with permission from Moors

730 for the Future. The work was supported by the University of Manchester through a

731 Graduate Teaching Fellowship and Investing in Success grant, awarded to CSG. 


\section{REFERENCES}

734

735 Allott TEH, Evans MG, Lindsay JB, Agnew CT, Freer JE, Jones A, Parnell M. 2009.

736 Water tables in Peak District blanket peatlands. Report No. 17, Moors for the Future:

737 Edale.

738

739 Bay RR. 1969. Runoff from small peatland watersheds. Journal of Hydrology 9: 90-

740102.

741

742 Beven KJ, Kirkby MJ. 1979. A physically based, variable contributing area model of 743 basin hydrology. Hydrological Sciences Bulletin 24: 43-69. DOI:

$744 \quad 10.1080 / 02626667909491834$

745

746 Bhamjee R, Lindsay JB. 2011. Ephemeral stream sensor design using state loggers.

747 Hydrology and Earth System Sciences 15 (3): 1009-1021. DOI: 10.5194/hess-15-

$748 \quad 1009-2011$

749

750

Blyth K, Rodda JC. 1973. A Stream Length Study. Water Resources Research 9:

751 1454-1461. DOI: 10.1029/WR009i005p01454

752

753 Bond NR, Cottingham P. 2008. Ecology and hydrology of temporary streams:

754 implications for sustainable water management. eWater Technical Report. eWater

755 Cooperative Research Centre, Canberra. 
757 Bower MM. 1961. The distribution of erosion in blanket peat bogs in the Pennines,

758 Transaction of the Institute of British Geographers 29: 17-30.

759

760 Bracken LJ, Croke J. 2007. The concept of hydrological connectivity and its

761 contribution to understanding runoff-dominated geomorphic systems. Hydrological

762 Processes 21 (13): 1749-1763. DOI: 10.1002/hyp.6313

\section{3}

764 Bracken LJ. Wainwright J. Ali GA, Tetzlaff D, Smith MW, Reaney SM, Roy AG. 2013.

765 Concepts of hydrological connectivity: Research approaches, pathways and future

766 agendas. Earth-Science Reviews 119: 17-34. DOI: 10.1016/j.earscirev.2013.02.001

767

768 Burt TP, Heathwaite AL, Labadz JC. 1990. Runoff production in peat covered-

769 catchments. In Process Studies in Hillslope Hydrology, Anderson MG, Burt TP (eds).

770 Wiley: Chichester; 463-500.

771

772 Butcher DP, Claydon J, Mice JC, Pattinson, VA, Potter AWR, White P. 1992

773 Reservoir sedimentation and colour problems in southern Pennine reservoirs. Water

774 and Environment Journal 6: 418-430. DOI: 10.1111/j.1747-6593.1992.tb00771.x

775

776 Clark JM, Gallego-Sala AV, Allott TEH, Chapman SJ, Farewell T, Freeman C, House

777 JI, Orr HG, Prentice IC, Smith P. 2010. Assessing the vulnerability of blanket peat to

778 climate change using an ensemble of statistical bioclimatic envelope models.

779 Climate Research 45 (1): 131-150. DOI: 10.3354/cr00929

780 
781 Crowe SK, Evans MG, Allott THE. 2008. Geomorphological controls on the re-

782 vegetation of erosion gullies in blanket peat: implications for bog restoration. Mires 783 and Peat 1: 1-14.

784

785

Daniels S. 2006. Controls on Streamwater Acidity in South Pennine Headwater

Catchments. Unpublished PhD Thesis, University of Manchester, 2006.

787

788

789

Daniels SM, Agnew CT, Evans MG, Allott TEH. 2008. Water table variability and runoff generation in a degraded peatland, South Pennines, UK. Journal of Hydrology

790

361: 214-226. DOI: 10.1016/j.jhydrol.2008.07.042

791

792

Day DG. 1978. Drainage density changes during Rainfall. Earth Surface Processes and Landforms 3: 319-326.

794

795

Day DG. 1980. Lithologic controls of drainage density: A study of six small rural

796

catchments in New England, N.S.W. Catena 7: 339-351.

797

798

Evans MG, Lindsay JB. 2010. High resolution quantification of gully erosion in

799

upland peatlands at the landscape scale. Earth Surface Processes and Landforms

800

35: 876-886. DOI: 10.1002/esp.1918

801

802 Evans, MG, Warburton J. 2005. Sediment budget for an eroding peat moorland

803 catchment in northern England. Earth Surface Processes and Landforms 30: 557-

804 577. DOI: 10.1002/esp.1153

805 
806 Evans MG, Warburton J. 2007. Geomorphology of Upland Peat: Erosion, Form, and

807 Landscape Change. Blackwell: Oxford.

808

809 Fritz KM, Johnson BR, Walters DM. 2008. Physical indicators of hydrologic

810 permanence in forested headwater streams. Journal of The North American

811 Benthological Society 27: 690-704. DOI: 10.1899/07-117.1

812

813 Fryirs KA, Brierley GJ, Preston NJ, Kasai M. 2007. Buffers, barriers and blankets:

814 The (dis)connectivity of catchment-scale sediment cascades. Catena 70 (1): 49-67.

815 DOI: 10.1016/j.catena.2006.07.007

816

817 Gomi T, Sidle RC, Miyata S, Kosugi K, Onda Y. 2008. Dynamic runoff connectivity of 818 overland flow on steep forested hillslopes: scale effects and runoff transfer. Water

819 Resources Research 44: W08411. DOI: 10.1029/2007WR005894

820

821 Goulsbra CS, Lindsay JB, Evans, MG. 2009. A new approach to the application of

822 electrical resistance sensors to measuring the onset of ephemeral stream flow in

823 wetland environments. Water Resources Research 45: W09501. DOI:

$824 \quad 10.1029 / 2009 W R 007789$

825

826 Gregory KJ, Ovenden JC. 1979. Drainage network volumes and precipitation in

827 Britain. Transactions of the Institute of British Geographers 4: 1-11.

828

829 Gregory KJ, Walling DE. 1968. The variation of drainage density within a catchment.

830 Bulletin of International Association of Scientific Hydrology 13: 61-68. 
831

832 Gurnell AM. 1978. The Dynamics of a Drainage Network. Nordic Hydrology 9: 293-

833306.

834

835

Holden J. 2006. Sediment and particulate carbon removal by pipe erosion increase

836

over time in blanket peats as a consequence of land drainage. Journal of

837 Geophysical Research 111 (F2) F02010. DOI: 10.1029/2005JF000386

838

839 Holden J, Burt, TP. 2002. Piping and pipeflow in a deep peat catchment. Catena 48:

840 163-199. DOI: 10.1016/S0341-8162(01)00189-8

841

842

Holden J, Burt TP. 2003. Runoff production in blanket peat covered catchments.

843 Water Resources Research 39: 1191, DOI: 10.1029/2002WR001956

844

845 Holden J, Evans MG, Burt TP, Horton M. 2006. Impact of land drainage on peatland

846 hydrology. Journal of Environmental Quality 35 (5): 1764-1778. DOI:

847

10.2134/jeq2005.0477

848

849

Kirkby MJ. 1975. Hydrograph modelling strategies. In Processes in physical and

850 human geography. Peel R, Chisholm M, Haggett P (eds). Heinemann: London; 69-

85190.

852

853 Lane SN, Brookes CJ, Kirkby MJ, Holden J. 2004. A network-index-based version of

854 TOPMODEL for use with high resolution digital topographic data. Hydrological

855 Processes 18: 191-201. DOI: 10.1002/hyp.5208 
857 Lexartza-Artza I, Wainwright J. 2009. Hydrological connectivity: linking concepts with

858 practical implications. Catena 79: 146-152. DOI: 10.1016/j.catena.2009.07.001

859

860 Lindsay JB. 2005. The Terrain Analysis System: A tool for hydro-geomorphic

861 applications. Hydrological Processes 19: 1123-1130. DOI: 10.1002/hyp.5818

862

863 McGuire KJ, McDonnell JJ. 2010. Hydrological connectivity of hillslopes and

864 streams: Characteristic time scales and nonlinearities. Water Resources Research

86546 (10): W10543. DOI: 10.1029/2010WR009341

866

867

Morgan RPC. 1972. Observations on Factors Affecting the Behaviour of a First-

868 Order Stream. Transactions of the Institute of British Geographers 56: 171-185.

869

870 Pawson RR, Evans MG, Allott TEH. 2012. Fluvial carbon flux from headwater

871 peatland streams: significance of particulate carbon flux. Earth Surface Processes

872 and Landforms 37: 1203-1212. DOI: 10.1002/esp.3257

873

874 Ramchunder SJ, Brown LE, Holden J, 2009. Environmental effects of drainage,

875 drain-blocking and prescribed vegetation burning in UK upland peatlands. Progress

876 in Physical Geography 33 (1): 49-79. DOI: 10.1177/0309133309105245

877

878 Reaney SM, Bracken LJ, Kirkby MJ. 2013. The importance of surface controls on

879 overland flow connectivity in semi-arid environments: results from a numerical

880 experimental approach. Hydrological Processes. DOI: 10.1002/hyp.9769 
881

882 Roberts MC, Klingeman PC. 1972. The relationship of drainage net fluctuation and

883 discharge. Paper presented at 22 International Geographical Congress, Canada.

884

885

Rothwell JJ, Evans MG, Daniels SM, Allott TEH. 2007. Baseflow and stormflow

886

metal concentrations in streams draining contaminated peat moorlands in the Peak

887 District National Park (UK). Journal of Hydrology 341: 90- 104. DOI:

888 10.1016/j.jhydrol.2007.05.004

889

890 Rothwell JJ, Robinson SG, Evans MG, Yang J, Allott TEH. 2005. Heavy metal

891

release by peat erosion in the Peak District, southern Pennines, UK. Hydrological

892

Processes 19: 2973-2989. DOI: 10.1002/hyp.5811

893

894

Smart RP, Holden J, Dinsmore KJ, Baird AJ, Billet MF, Chapman PJ, Grayson R.

895

2013. The dynamics of natural pipe hydrological behaviour in blanket peat.

896

Hydrological Processes 27: 1523-1534. DOI: 10.1002/hyp.9242

897

898

Wainwright J, Turnbull L, Ibrahim TG, Lexartza-Artza I, Thornton SF, Brazier RE.

899

2011. Linking environmental régimes, space and time: Interpretations of structural

900 and functional connectivity. Geomorphology 126 (3-4): 387-404. DOI:

$901 \quad$ 10.1016/j.geomorph.2010.07.027

902

903 Wallett CV. 2004. The Importance of Pipeflow to the Flux of Carbon from an Upland

904 Peat. Unpublished M.Sc. Thesis, The University of Manchester.

905 
906 Wharton G. 1994. Progress in the use of drainage network indices for rainfall-runoff

907 modelling and runoff prediction. Progress in Physical Geography 18: 539-557. DOI:

$908 \quad 10.1177 / 030913339401800404$

909

910 Wigington PJ Jr., Moser T J, Lindeman DR. 2005. Stream network expansion: A

911 riparian water quality factor. Hydrological Processes 19: 1715- 1721. DOI:

$912 \quad 10.1002 /$ hyp.5866

913

914 Worrall F, Burt TP, Jaeban RY, Warburton J, Shedden R. 2002. Release of

915 dissolved organic carbon from upland peat. Hydrological Processes 16: 3486-3504.

916 DOI: $10.1002 /$ hyp.1111

917

918 Worrall F, Reed M, Warburton J, Burt T. 2003. Carbon budget for a British upland

919 peat catchment. Science of the Total Environment 312: 133-146. DOI:

$920 \quad 10.1016 / S 0048-9697(03) 00226-2$ 
TABLES

\begin{tabular}{|c|c|c|c|}
\hline $\begin{array}{l}\text { Drainage } \\
\text { Density, } \\
\left(\mathbf{k m} / \mathbf{k m}^{2}\right) \\
\end{array}$ & $\begin{array}{l}\text { Size of } \\
\text { Basin } \\
\left(\mathrm{km}^{2}\right)\end{array}$ & Comments & Source \\
\hline $0.8-3.5$ & 0.08 & \multirow{2}{*}{$\begin{array}{l}1 \text { year of observation; Devon } \\
\text { England }\end{array}$} & \multirow{2}{*}{$\begin{array}{l}\text { Gregory and } \\
\text { Walling (1968) }\end{array}$} \\
\hline $0.9-6.5$ & 0.16 & & \\
\hline $0.6-3.7$ & 0.10 & \multirow{4}{*}{$\begin{array}{l}2 \text { years of observations; Oregon, } \\
\text { U.S.A. }\end{array}$} & \multirow{4}{*}{$\begin{array}{l}\text { Roberts and } \\
\text { Klingeman (1972) }\end{array}$} \\
\hline $1.2-10.9$ & 0.01 & & \\
\hline $3.1-4.2$ & 0.26 & & \\
\hline $1.5-3.4$ & 0.23 & & \\
\hline $0.8-2.7$ & 18.56 & $\begin{array}{l}1 \text { year of observations; } \\
\text { Buckinghamshire, England }\end{array}$ & $\begin{array}{l}\text { Blyth and Rodda, } \\
(1973)\end{array}$ \\
\hline $3.9-5.8$ & 0.26 & $\begin{array}{l}3 \text { years of observation; } \\
\text { preurbanisation, Devon, England }\end{array}$ & \multirow[t]{2}{*}{ Gregory (1976) } \\
\hline $5.0-17.6$ & 0.26 & $\begin{array}{l}1 \text { year of observation; } \\
\text { posturbanisation, Devon, } \\
\text { England }\end{array}$ & \\
\hline $0.7-5.4$ & 0.12 & $\begin{array}{l}2 \text { storms; New South Wales, } \\
\text { Australia }\end{array}$ & Day (1978) \\
\hline $0.0-3.4$ & 0.15 & \multirow{6}{*}{$\begin{array}{l}1 \text { year of observation; New South } \\
\text { Wales, Australia }\end{array}$} & \multirow[t]{6}{*}{ Day (1980) } \\
\hline $0.5-5.2$ & 0.20 & & \\
\hline $0.0-1.8$ & 0.07 & & \\
\hline $0.0-7.5$ & 0.08 & & \\
\hline $0.0-7.7$ & 0.10 & & \\
\hline $0.0-16.7$ & 0.02 & & \\
\hline $0.2-8.0$ & 47.8 & \multirow{5}{*}{$\begin{array}{l}\text { Summer and Winter (aerial } \\
\text { photography); Western Oregon, } \\
\text { USA }\end{array}$} & \multirow{5}{*}{$\begin{array}{l}\text { Wingington et al. } \\
(2005)\end{array}$} \\
\hline $0.6-4.7$ & 23.6 & & \\
\hline $0.4-3.3$ & 37.3 & & \\
\hline $0.5-2.9$ & 37.1 & & \\
\hline $0.66-3.23$ & 21.6 & & \\
\hline
\end{tabular}

Table 1.Variations in drainage density found by previous studies. 


\begin{tabular}{|c|c|c|}
\hline $\begin{array}{l}\text { Data } \\
\text { Source }\end{array}$ & $\begin{array}{l}\text { Sitel } \\
\text { Catchment }\end{array}$ & Characteristic \\
\hline \multirow{3}{*}{$\begin{array}{l}\text { Field } \\
\text { Data }\end{array}$} & \multirow{3}{*}{$\begin{array}{l}\text { Site } \\
\text { specific }\end{array}$} & Gully Depth (m) \\
\hline & & Gully Top Width (m) \\
\hline & & Gully Floor Width (m) \\
\hline \multirow{13}{*}{$\begin{array}{l}\text { LiDAR } \\
\text { Data }\end{array}$} & \multirow{4}{*}{$\begin{array}{l}\text { Site } \\
\text { specific }\end{array}$} & Elevation $(\mathrm{m})$ \\
\hline & & Network Wetness Index \\
\hline & & Gully Depth (m) \\
\hline & & $\begin{array}{l}\text { Channel Slope (one, two, three and four grid-cells } \\
\text { either side of site) }(\%)\end{array}$ \\
\hline & \multirow{5}{*}{$\begin{array}{l}\text { Catchment } \\
\text { of each site }\end{array}$} & Area of Catchment $\left(\mathrm{m}^{2}\right)$ \\
\hline & & Mean Slope of Catchment (\%) \\
\hline & & Mean Wetness Index of Catchment \\
\hline & & Proportion of catchment area occupied by gullies (\%) \\
\hline & & Average gully depth in catchment $(\mathrm{m})^{*}$ \\
\hline & \multirow{4}{*}{$\begin{array}{l}\text { Catchment } \\
\text { of each site } \\
\text { excluding } \\
\text { gullies }\end{array}$} & Area of Catchment $\left(\mathrm{m}^{2}\right)$ \\
\hline & & Mean Slope of Catchment (\%) \\
\hline & & Mean Water Table Depth of Catchment $(\mathrm{mm})^{\star *}$ \\
\hline & & Mean Wetness Index of Catchment \\
\hline
\end{tabular}

Table 2. Spatial data collected for each site.

* Extracted from the gully map of the catchment (Evans and Lindsay, 2010)

${ }^{* *}$ Extracted from the water table model for the catchment (Allott et al., 2009)

\begin{tabular}{|c|c|c|c|c|c|c|c|}
\hline $\begin{array}{c}19 / 09 / 07 \\
n=23\end{array}$ & $\begin{array}{c}\mathrm{R}=0.58 \\
\text { Sig. } 0.08 \\
n=10\end{array}$ & & & & & & \\
\hline $\begin{array}{c}20 / 09 / 07 \\
n=18\end{array}$ & $n=1$ & $n=3$ & & & & & \\
\hline $\begin{array}{c}03 / 10 / 07 \\
n=10\end{array}$ & $n=0$ & $n=2$ & $n=8$ & & & & \\
\hline $\begin{array}{c}08 / 10 / 07 \\
n=11\end{array}$ & $n=4$ & $\begin{array}{c}\mathrm{R}=0.71 \\
\text { Sig. } 0.02 \\
n=10\end{array}$ & $n=2$ & $n=2$ & & & \\
\hline $\begin{array}{c}09 / 10 / 07 \\
n=19\end{array}$ & $n=0$ & $n=3$ & $\begin{array}{c}\mathrm{R}=0.54 \\
\text { Sig. } 0.04 \\
n=15\end{array}$ & $\begin{array}{c}\mathrm{R}=0.84 \\
\text { Sig. } 0.00 \\
n=10\end{array}$ & $n=2$ & & \\
\hline $\begin{array}{c}28 / 10 / 07 \\
n=19\end{array}$ & $n=0$ & $n=4$ & $\begin{array}{c}\mathrm{R}=0.63 \\
\text { Sig. } 0.01 \\
n=15\end{array}$ & $n=8$ & $n=4$ & $\begin{array}{c}\mathrm{R}=0.85 \\
\text { Sig. } 0.00 \\
n=16\end{array}$ & \\
\hline \multirow[t]{2}{*}{$\begin{array}{c}05 / 11 / 07 \\
n=13\end{array}$} & $n=0$ & $n=1$ & $\begin{array}{c}\mathrm{R}=0.11 \\
\text { Sig. } 0.75 \\
n=11\end{array}$ & $n=6$ & $n=0$ & $\begin{array}{c}\mathrm{R}=-0.07 \\
\text { Sig. } 0.83 \\
n=12\end{array}$ & $\begin{array}{c}\mathrm{R}=-0.07 \\
\text { Sig. } 0.82 \\
n=13\end{array}$ \\
\hline & $\begin{array}{c}10 / 0 / 07 \\
n=10\end{array}$ & $\begin{array}{c}19 / 09 / 07 \\
n=23\end{array}$ & $\begin{array}{c}20 / 09 / 07 \\
n=18\end{array}$ & $\begin{array}{c}03 / 10 / 07 \\
n=10\end{array}$ & $\begin{array}{c}08 / 10 / 07 \\
n=11\end{array}$ & $\begin{array}{c}09 / 10 / 07 \\
n=19\end{array}$ & $\begin{array}{c}28 / 10 / 07 \\
n=19\end{array}$ \\
\hline
\end{tabular}

Table 3. Results of Spearman's rank correlation analysis for network expansion events in the 2007 dataset. The order in which sites went from dry to wet was compared for pairs of events where ten or more sites responded to both events. 


\begin{tabular}{|c|c|c|c|c|c|}
\hline $\begin{array}{c}30 / 07 / 08 \\
n=10\end{array}$ & $\begin{array}{c}\mathrm{R}=0.60 \\
\text { Sig. } 0.07 \\
\mathrm{n}=10\end{array}$ & & & & \\
\hline $\begin{array}{c}31 / 07 / 08 \\
n=17\end{array}$ & $\begin{array}{c}R=0.22 \\
\text { Sig. } 0.40 \\
n=17\end{array}$ & $n=4$ & & & \\
\hline $\begin{array}{c}01 / 08 / 08 \\
n=18\end{array}$ & $\begin{array}{c}R=0.70 \\
0.00 \\
n=17\end{array}$ & $n=7$ & $n=2$ & & \\
\hline $\begin{array}{c}03 / 08 / 08 \\
n=12\end{array}$ & $\begin{array}{c}\mathrm{R}=0.35 \\
\text { Sig. } 0.27 \\
\mathrm{n}=12\end{array}$ & $n=6$ & $n=2$ & $\begin{array}{c}\mathrm{R}=0.66 \\
\text { Sig. } 0.04 \\
n=10\end{array}$ & \\
\hline \multirow[t]{2}{*}{$\begin{array}{c}16 / 08 / 08 \\
n=19\end{array}$} & $\begin{array}{c}\mathrm{R}=0.43 \\
\text { Sig. } 0.07 \\
\mathrm{n}=19\end{array}$ & $n=6$ & $n=7$ & $\begin{array}{c}\mathrm{R}=0.79 \\
\text { Sig. } 0.00 \\
\mathrm{n}=12\end{array}$ & $\begin{array}{c}\mathrm{R}=0.58 \\
\text { Sig. } 0.08 \\
\mathrm{n}=10\end{array}$ \\
\hline & $\begin{array}{c}29 / 07 / 08 \\
n=39\end{array}$ & $\begin{array}{c}30 / 07 / 08 \\
n=10\end{array}$ & $\begin{array}{c}31 / 07 / 08 \\
n=17\end{array}$ & $\begin{array}{c}01 / 08 / 08 \\
n=18\end{array}$ & $\begin{array}{c}03 / 08 / 08 \\
n=12\end{array}$ \\
\hline
\end{tabular}

Table 4. Results of Spearman's rank correlation analysis for network expansion events in the 2008 dataset. The order in which sites went from dry to wet was compared for pairs of events where ten or more sites responded to both events.

\begin{tabular}{|l|l|r|r|r|r|r|}
\hline Date of & Number of & \multicolumn{3}{|c|}{ Cumulative sites wet (\% of total which respond) } \\
\cline { 2 - 7 } & $\begin{array}{l}\text { sites } \\
\text { which } \\
\text { respond } \\
\text { to event }\end{array}$ & Hour 1 & Hour 2 & Hour 3 & Hour 4 & Hour 5 \\
\hline $09 / 10 / 07$ & 19 & $4(21 \%)$ & $7(37 \%)$ & $17(89 \%)$ & $19(100 \%)$ & \\
\hline $28 / 10 / 07$ & 19 & $5(26 \%)$ & $14(74 \%)$ & $19(100 \%)$ & & \\
\hline $05 / 11 / 07$ & 13 & $13(100 \%)$ & & & & \\
\hline $31 / 07 / 08$ & 17 & $0(0 \%)$ & $13(76 \%)$ & $15(88 \%)$ & $17(100 \%)$ & \\
\hline $01 / 08 / 08$ & 18 & $12(67 \%)$ & $17(94 \%)$ & $18(100 \%)$ & & \\
\hline $16 / 08 / 08$ & 19 & $13(68 \%)$ & $14(74 \%)$ & $16(84 \%)$ & $17(89 \%)$ & $19(100 \%)$ \\
\hline
\end{tabular}

Table 5. The timing of streamflow initiation for large events. Events represent the occasions during the study period on which the highest number of sites went from dry to wet, with the exception of the examples shown in Figures 2 and 3. 

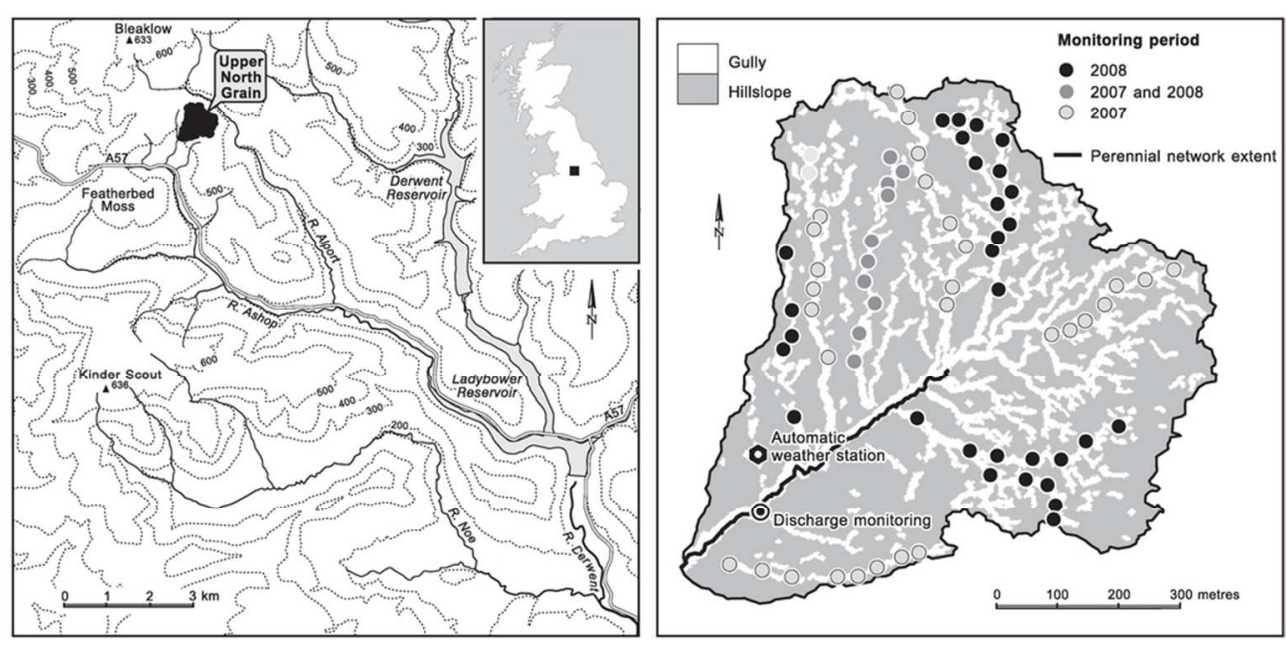

Figure 1. Location, topography and instrumentation of the Upper North Grain catchment, South Pennines, UK.

$88 \times 45 \mathrm{~mm}(300 \times 300 \mathrm{DPI})$ 

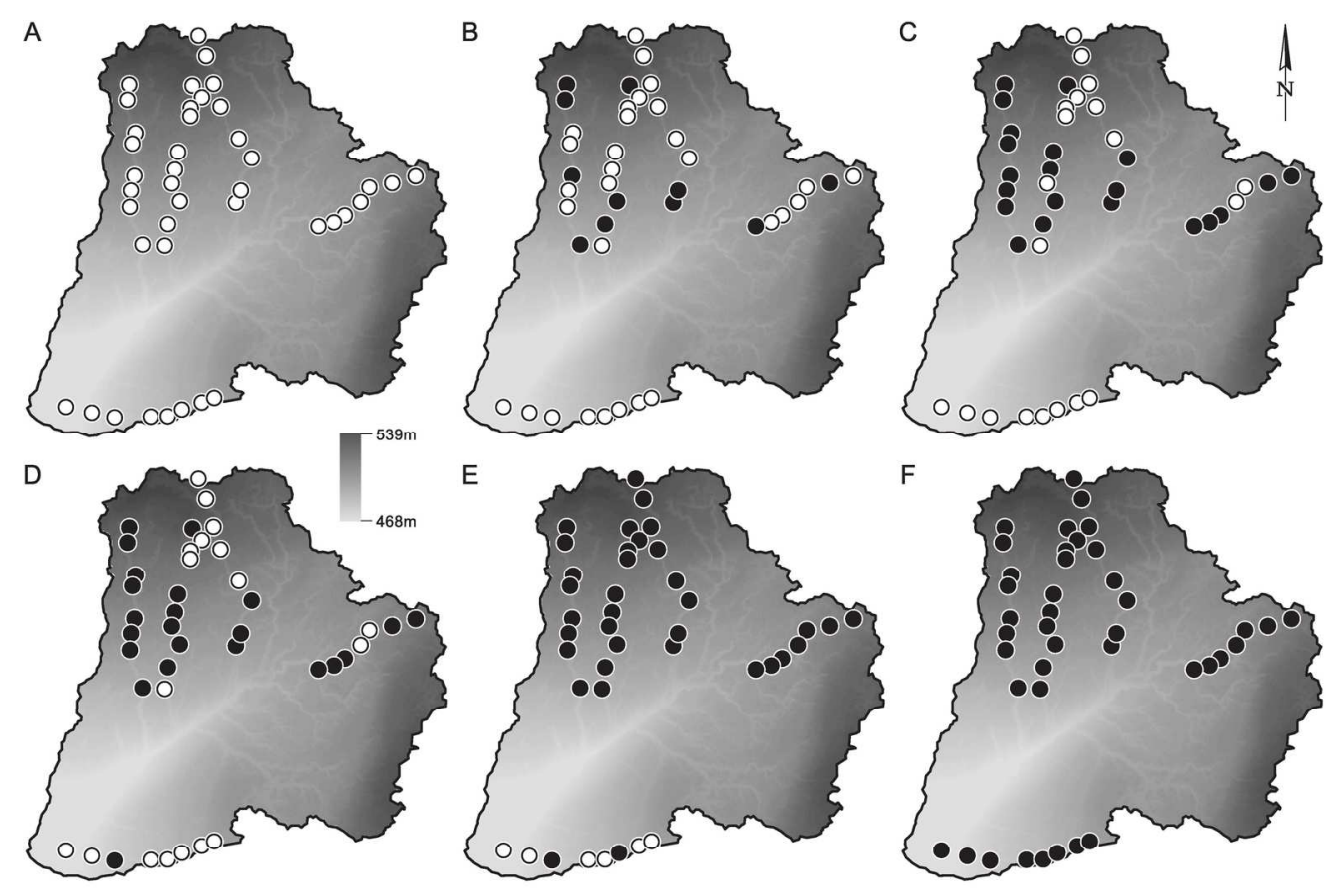

E
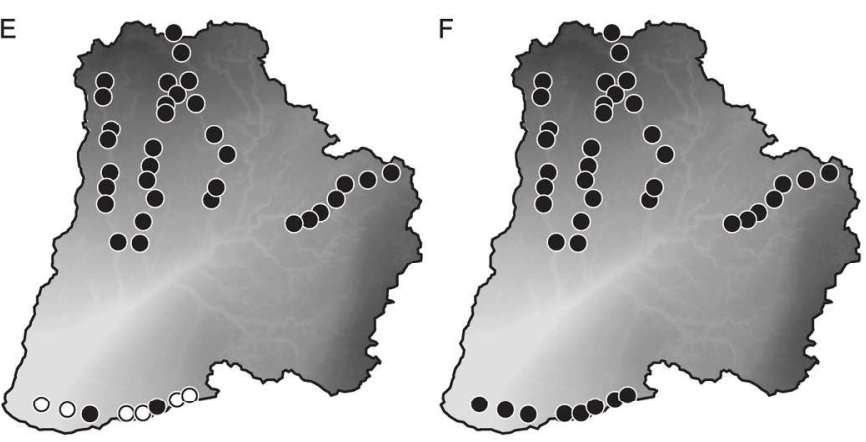

\begin{tabular}{llllll}
$0 \quad 100 \quad 200$ & $300 \quad 400 \quad 500$ & metres \\
\hline
\end{tabular}

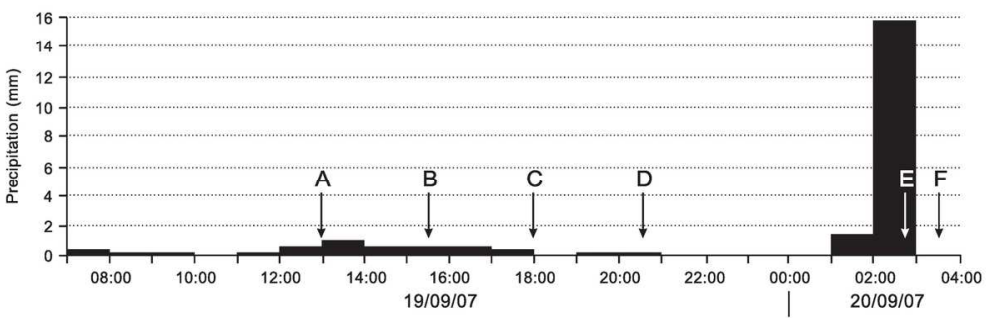

Figure 2. The pattern and timing of streamflow initiation during a large event on 19-20 Sept 2007. The white circles represent dry sites; the black circles represent wet sites. (A) 19/09/07 13:00; (B) 19/09/07 15:30;

(C) $19 / 09 / 0718: 00$; (D) 19/09/07 20:30; (E) 20/09/07 02:45; (F) 20/09/07 03:30. $168 \times 160 \mathrm{~mm}(300 \times 300 \mathrm{DPI})$ 

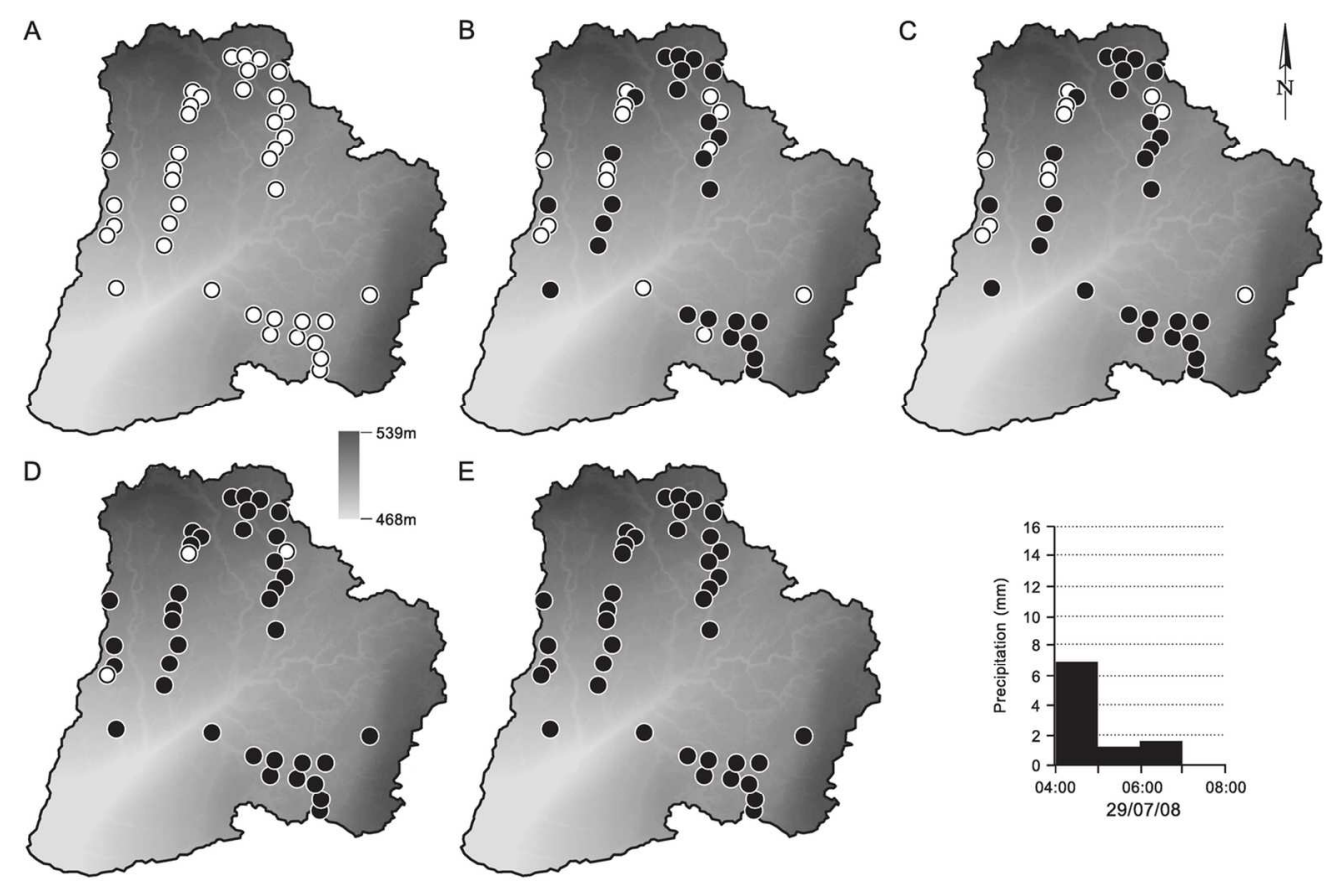

E
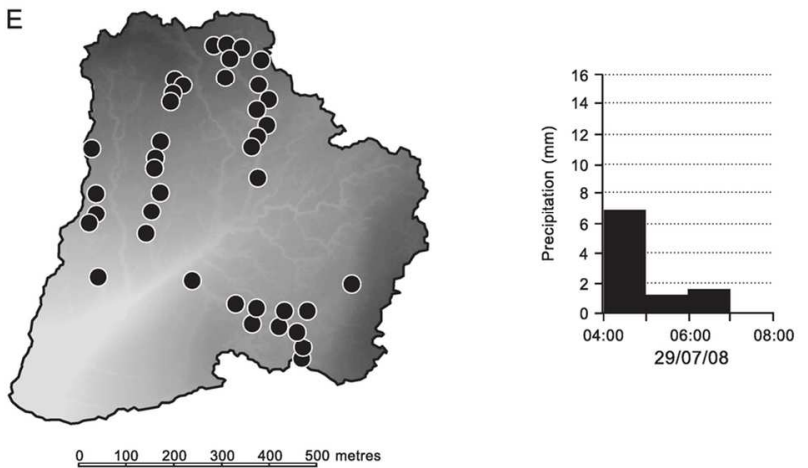

Figure 3. The pattern and timing of streamflow initiation during a large event on 29 July 2008. The white circles represent dry sites; the black circles represent wet sites. (A) 04:00; (B) 05:00; (C) 06:00; (D) 07:00; (E) 08:00. $122 \times 84 \mathrm{~mm}(300 \times 300 \mathrm{DPI})$ 

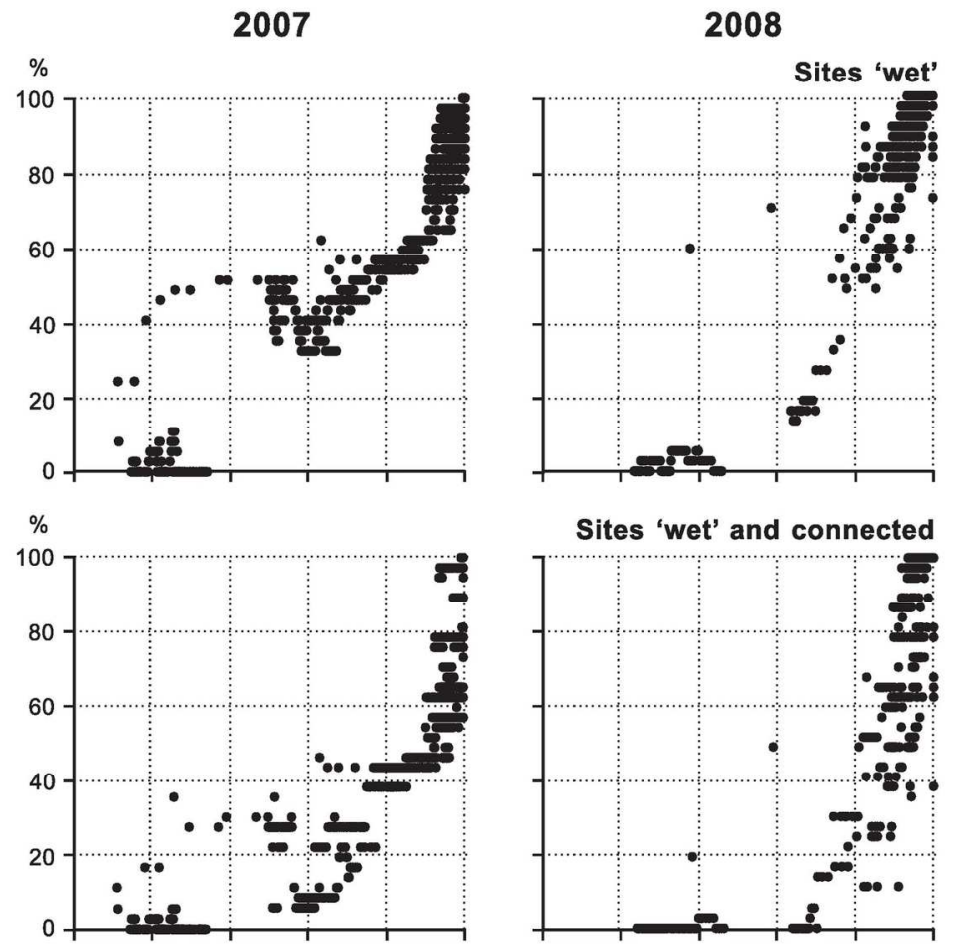

Sites 'wet' and connected
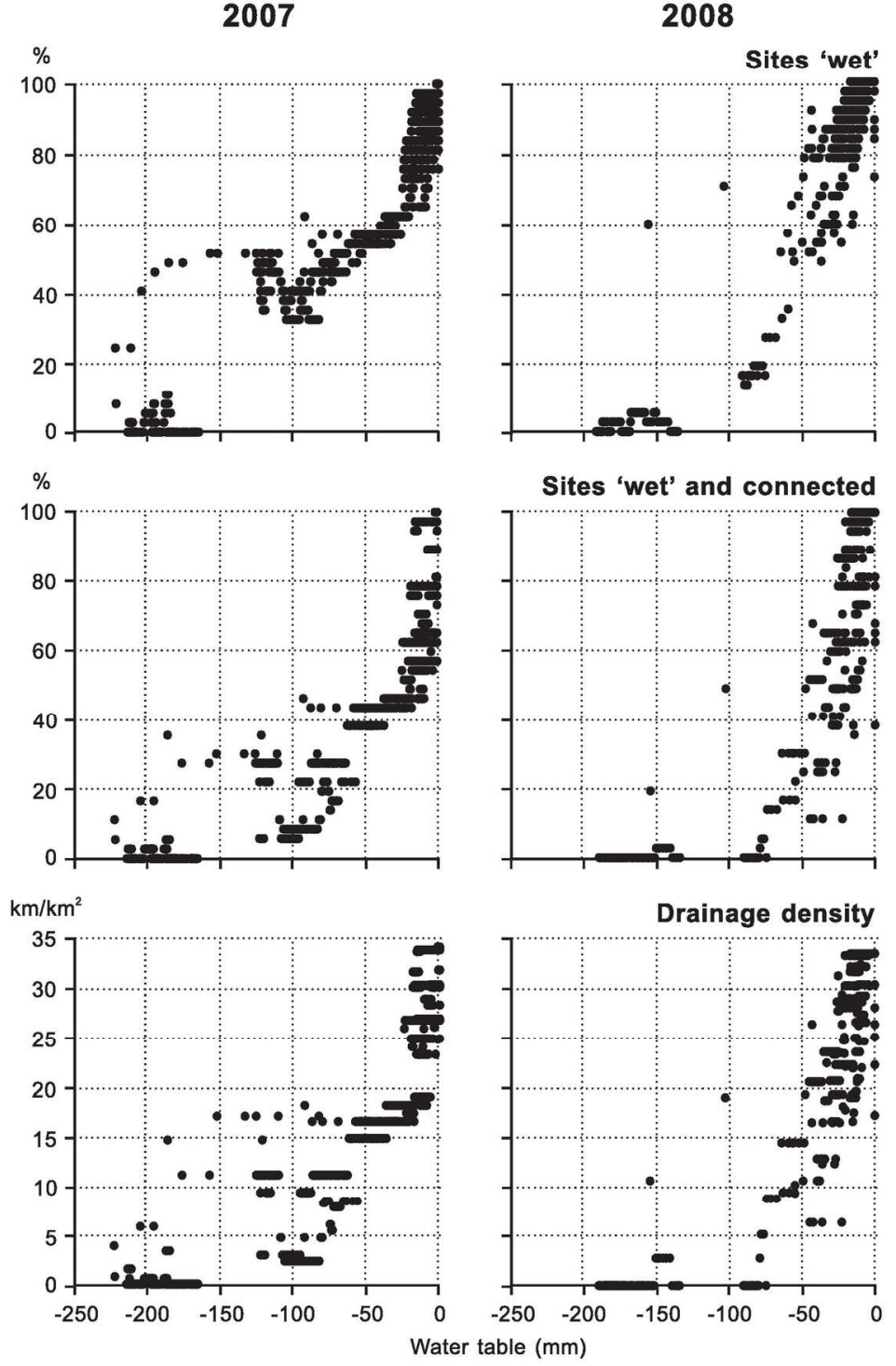

Figure 4. The relationships between water table depth and descriptors of network extent during the 2007 and 2008 study periods. $130 \times 196 \mathrm{~mm}(300 \times 300 \mathrm{DPI})$ 

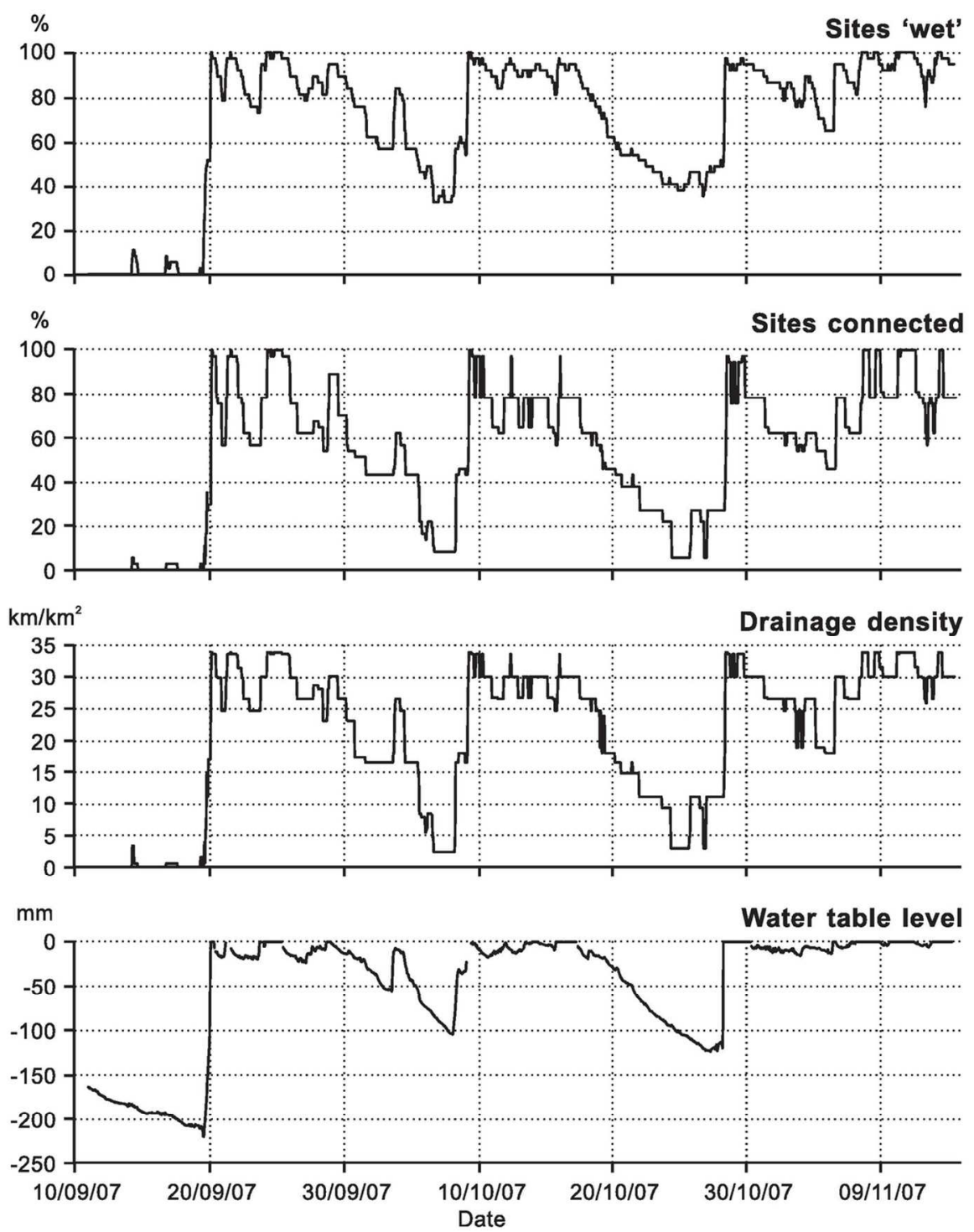

Figure 5. The variation in network extent and water table depth over the 2007 monitoring period. $114 \times 142 \mathrm{~mm}(300 \times 300 \mathrm{DPI})$ 

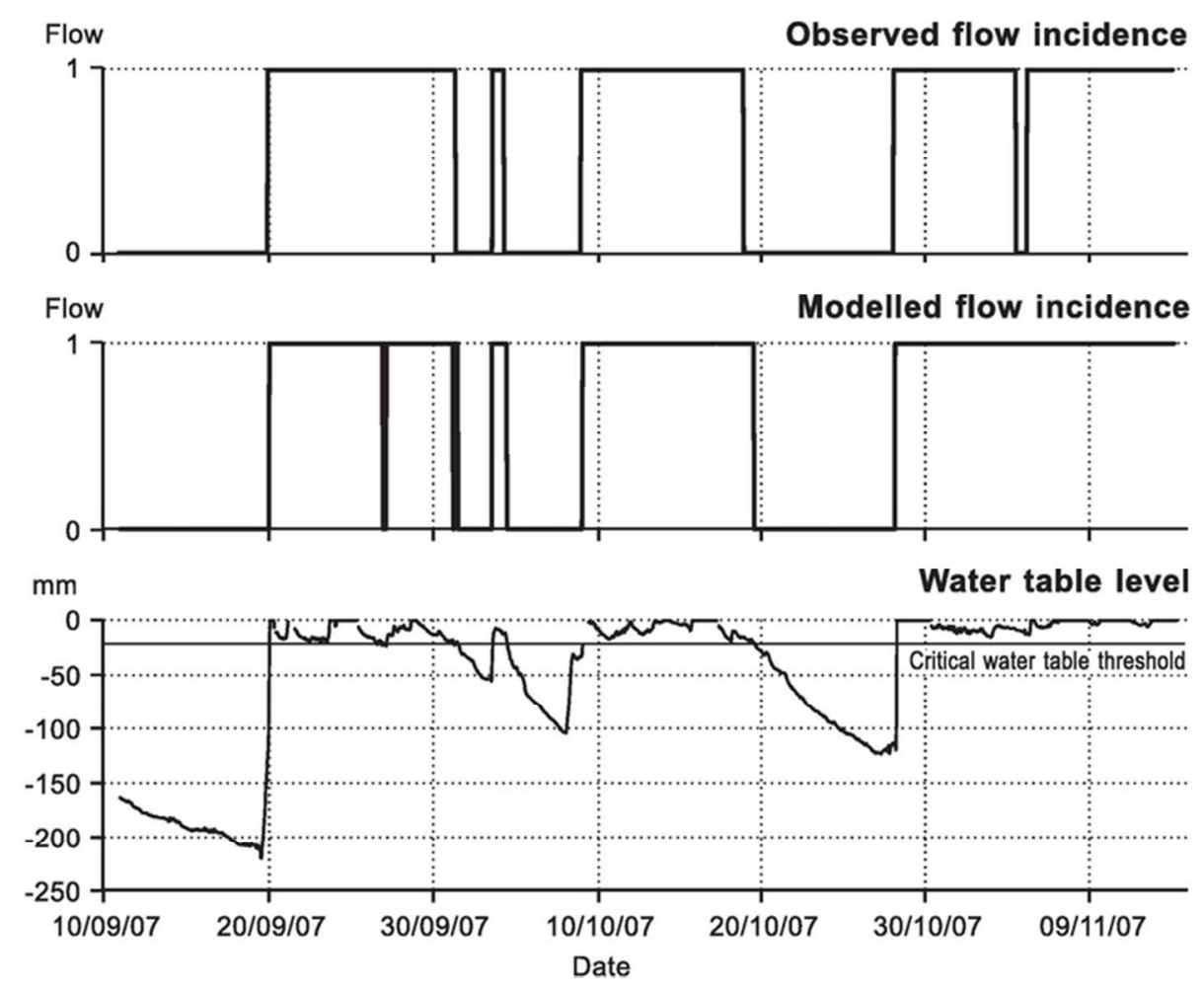

Figure 6. Observed (top) and modelled (centre) flow at one site, 2007. Water table depth (bottom) shows a critical threshold of $22.6 \mathrm{~mm}$, above which flow was registered at the site. $68 \times 50 \mathrm{~mm}(300 \times 300 \mathrm{DPI})$ 


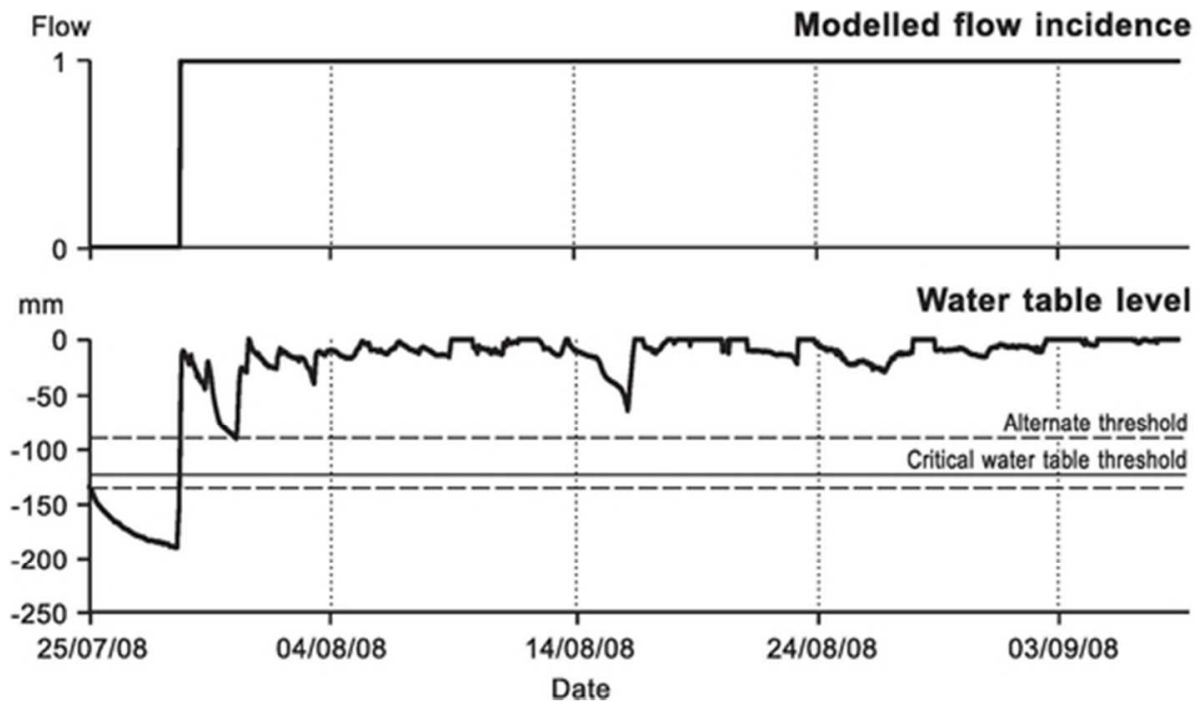

Figure 7. Modelled flow at one site, 2008 (top) and water table depth (bottom), showing the degree of uncertainty in critical water table depth at this site. $49 \times 26 \mathrm{~mm}(300 \times 300 \mathrm{DPI})$ 


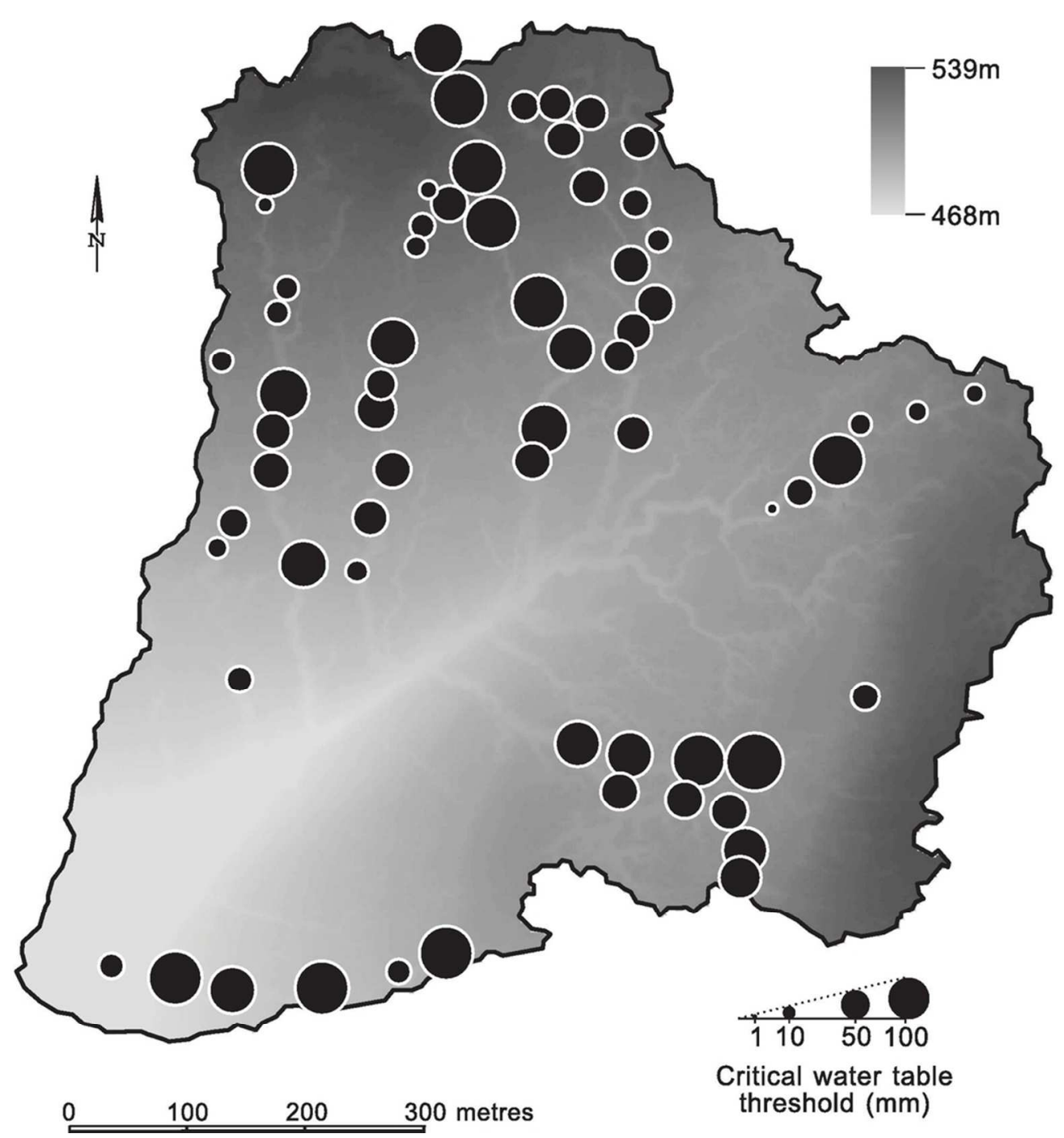

Figure 8 . The spatial distribution of critical water table depth. Larger circles represent wetter sites. $88 \times 93 \mathrm{~mm}(300 \times 300 \mathrm{DPI})$ 


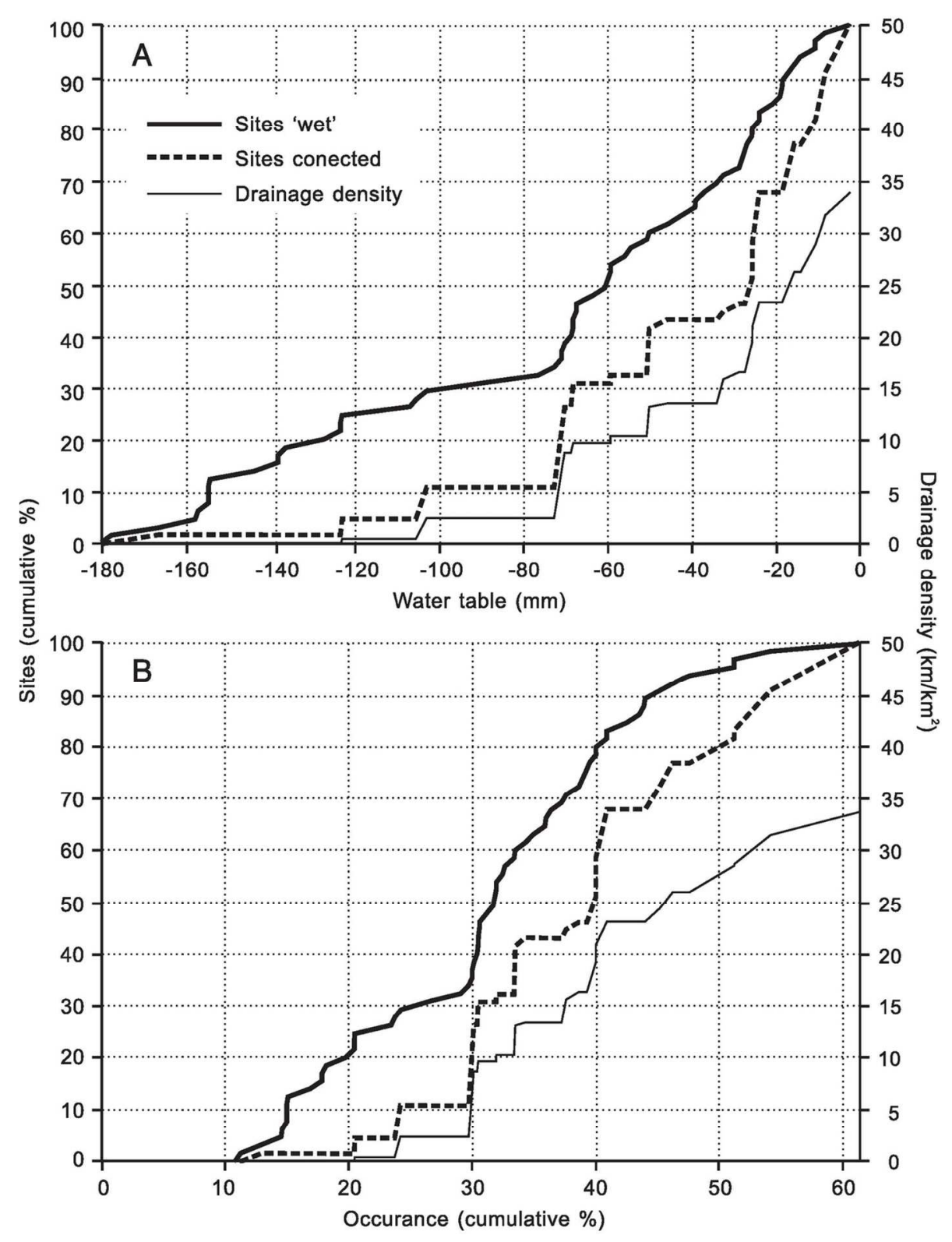

Figure 9. (A) The variation in network extent with water table depth; (B) The frequency at which these network extents are observed. $111 \times 147 \mathrm{~mm}(300 \times 300 \mathrm{DPI})$ 


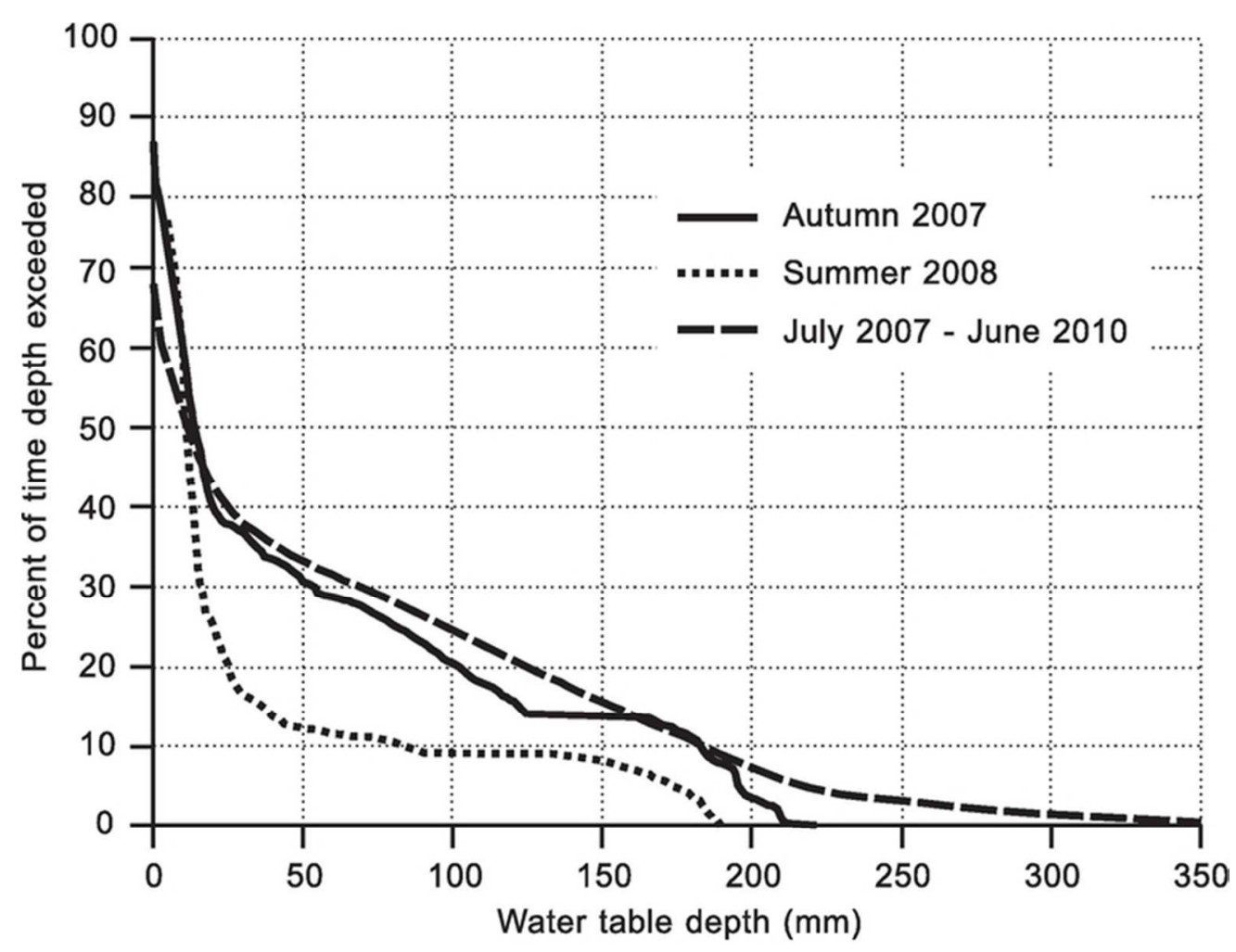

Figure 10. The distribution of water table depths during the 2007 and 2008 study periods and the longer term distribution of water table depths, using data from July 2007 to June 2010. $63 \times 48 \mathrm{~mm}(300 \times 300 \mathrm{DPI})$ 


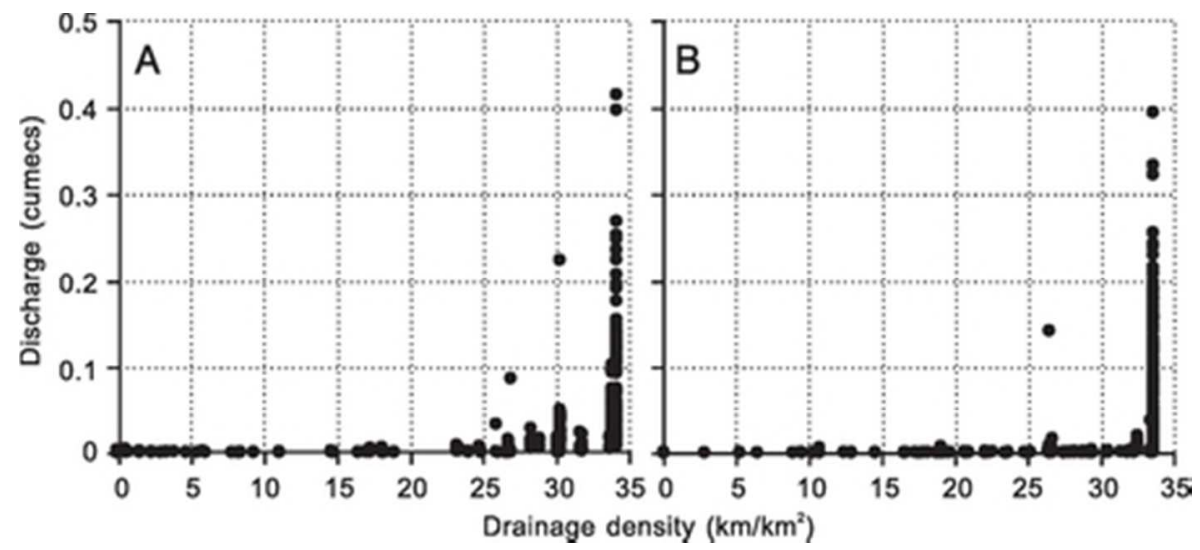

Figure 11. The relationship between drainage density and discharge at hourly intervals, in (A) 2007 $(n=1549)$, and (B) $2008(n=1081)$. $38 \times 17 \mathrm{~mm}(300 \times 300$ DPI $)$ 

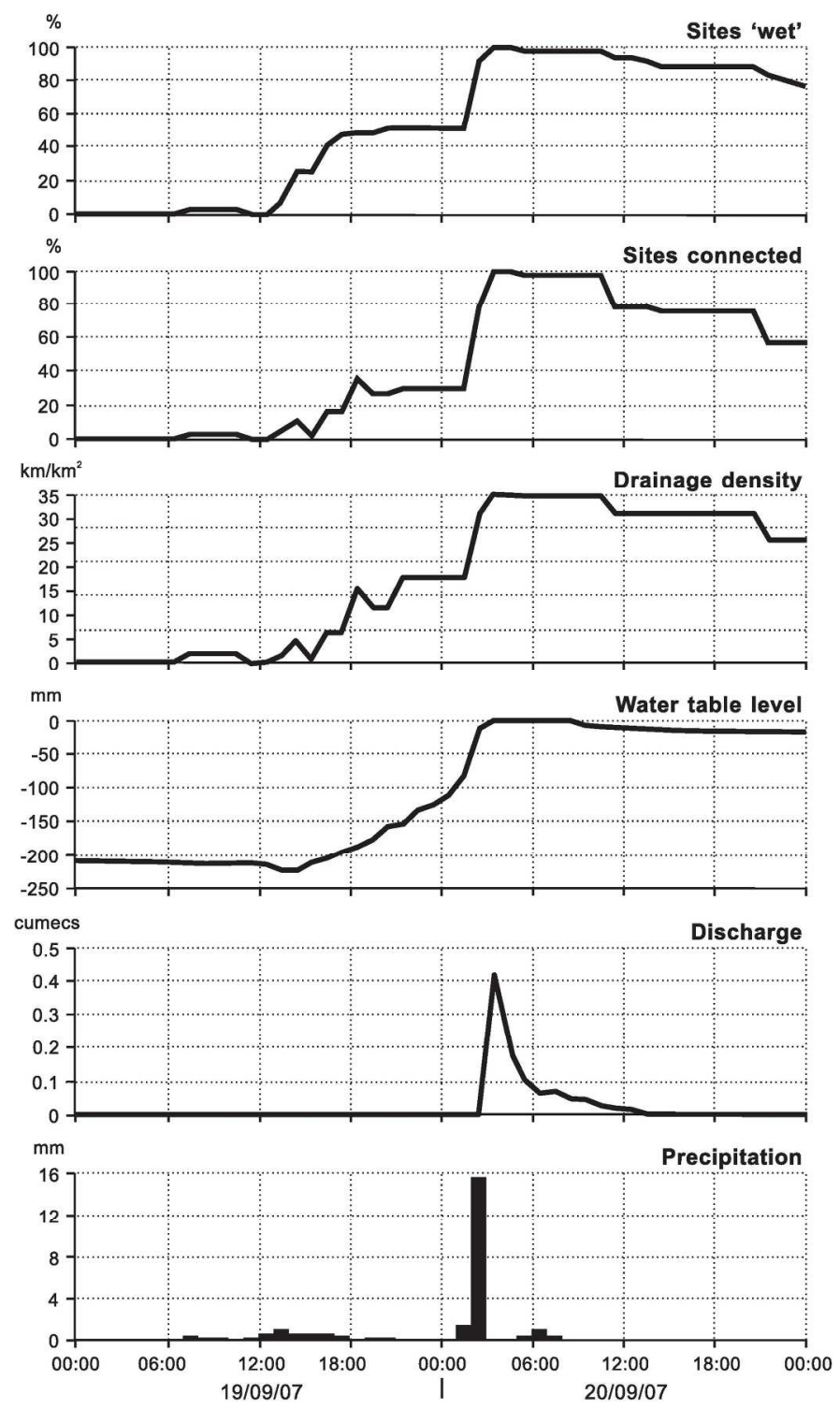

Figure 12. The variation in network extent, water table and discharge over the course of a storm on 19-20 September 2007. $152 \times 256 \mathrm{~mm}(300 \times 300 \mathrm{DPI})$ 